\title{
Sedimentology and diagenesis as 'hydrocarbon exploration tools' in the Late Permian Zechstein-2 Carbonate Member (NE Netherlands)
}

\author{
T.J.A. Reijers \\ Geo-Training \&Travel, Gevelakkers 11, 9465 TV Anderen, The Netherlands; e-mail: tjareijers@hetnet.nl
}

\begin{abstract}
Hydrocarbon exploration in The Netherlands has a chequered history from serendipitous oil shows via chance oil/ gas discoveries to finding the largest continental European oil field in 1943, followed by finding the largest gas field in the world in 1959. The present contribution traces the development of moderate to good porosity/permeability trends in depositional facies of Zechstein Stassfurt carbonates in a 'gas play' intermediate in significance between the above two plays but all in the northern part of The Netherlands.

Various depositional facies in the Stassfurt carbonates were turned into 'carbonate fabric units' by diagenetic processes creating or occluding the porosity/permeability. This formed moderate to good gas reservoirs in barrier-shoal, open-marine shelf and proximal-slope carbonates in the subsurface of the province of Drenthe in the NE Netherlands. The diagenetic models forming these carbonate fabric units are linked to the variety of facies in a depositional model which shows explain and predicts the reservoir trends. Such depositional/diagenetic facies are 'translated' into characteristic petrophysical values recognisable on wire line logs in uncored wells, and in characteristic seismic expressions that show these trends in undrilled areas. This approach has been proven to be effective in delineating porosity trends, visualised by 3-D seismic in the Collendoornerveen field, and thus provides a new exploration 'tool' in hydrocarbon exploration .
\end{abstract}

Keywords: hydrocarbons, Zechstein, reservoir modelling, 3-D seismic, The Netherlands

\section{Introduction}

Some fortuitous events rather than diligent examination of the initial scarce subsurface data guided early exploration for hydrocarbons in The Netherlands. A strong oil smell was noticed and gas bubbles were observed in cores from basal Zechstein carbonates and Carboniferous sandstones in the coal/salt-exploration Corle-1 well (1923) near Winterswijk in the east of the country. This triggered interest in the Zechstein carbonates as prospective reservoirs. In 1932, a predecessor of Shell Internationale Petroleum Maatschappij (SIPM) obtained a prospecting licence for the NE part of The Netherlands to actively chase the shows. It started the first systematic data gathering by a gravimetric survey and subsequently drilled 12 unsuccessful exploration wells. In 1938, a major blow-out occurred at Zechstein carbonate level at Bad Bentheim in Germany, about $10 \mathrm{~km}$ beyond the Dutch border. It was the first direct evidence of the presence at Zechstein level of gas in commercial quantities. The blow-out was killed after some 270 million $\mathrm{m}^{3}$ of gas, $6 \%$ of the field's reserves, had been expelled into the atmosphere.

In 1948, the Nederlandse Aardolie Maatschappij (NAM, a subsidiary of SIPM and Esso) 


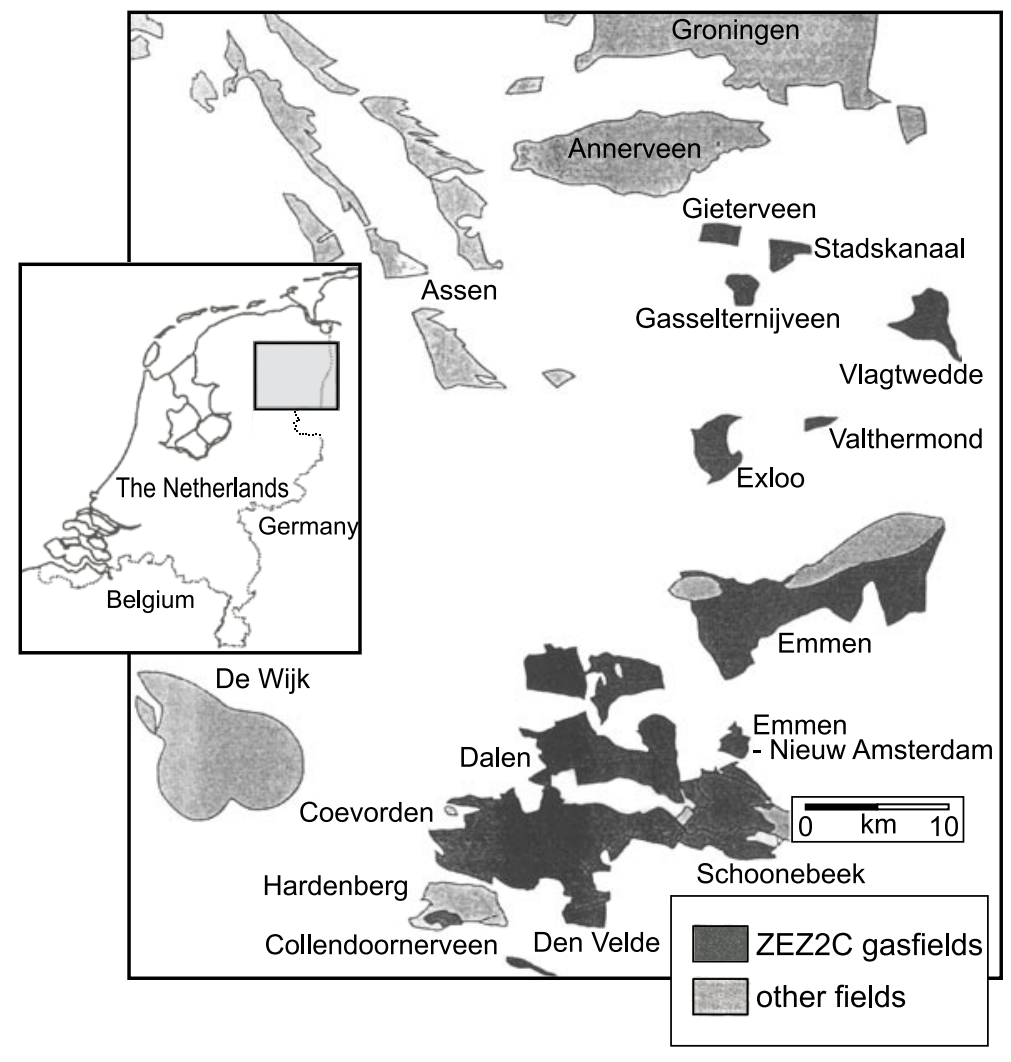

Fig. 1. Map of the NE Netherlands showing most Zechstein-2 Carbonate Member (ZEZ2C) gas fields and some other fields, and the existing 3-D seismic coverage (reproduced, with permission from Springer Verlag, from: Van de Sande et al., 1996). acquired operatorship in The Netherlands. It found the first gas field in the Netherlands,

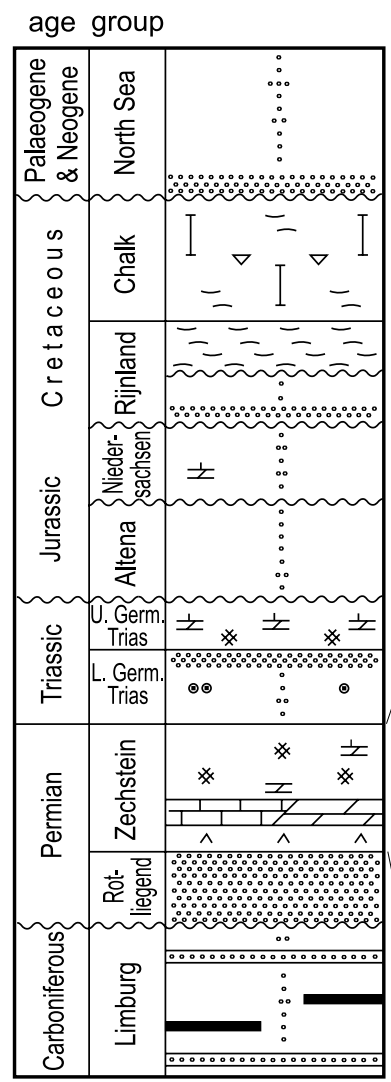

at Late Permian Zechstein carbonate level, at Coevorden still in the same year (Fig. 1). The Dutch 'oil' market was, however, not yet ready for 'gas'. This changed with the discovery of the giant Groningen gas field in 1959, producing from Early Permian Rotliegendes sandstone reservoirs. It was partly the result of the application of 2-D seismic from the 1950s onwards, initially single-fold but rapidly evolving into higher-quality multiple folds, and from the 1980s into 3-D seismic. This allowed an increasingly clear appreciation of potential gas and oil traps. Since the discovery of the Coevorden gas field, NAM has actively pursued the exploration of the Zechstein-2 carbonate play in the SE Drenthe area. It has resulted in the discovery of some 20 gas fields (Fig. 1) with cumulative reserves of some $57 \times 10^{9} \mathrm{~m}^{3}$ in the Zechstein-2 Carbonate (ZEZ2C) Member, part of the informal 'Basal Zechstein Unit' (Fig. 2),

Fig. 2. Generalised stratigraphy of the NE Netherlands, detailing the 'Basal Zechstein Unit', an informal unit in the Zechstein Group, of which the further subdivision is shown in Figure 3 (reproduced, with permission from Springer Verlag, from Van de Sande et al., 1996). 


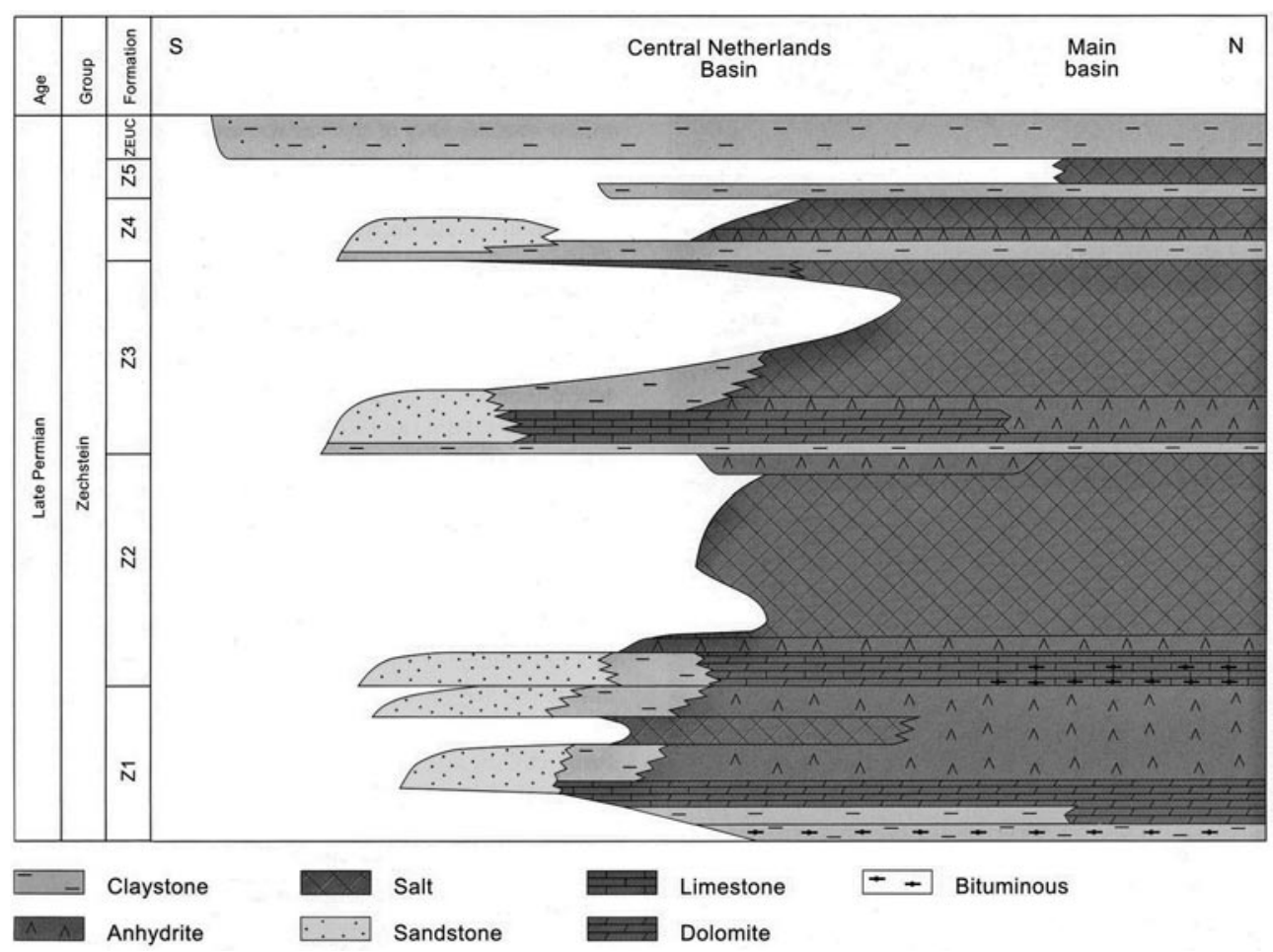

Fig. 3. Stratigraphy of the 'Late' Permian through the central and eastern Netherlands. Note the sandy 'Fringe Zechstein Member' close to the basin coast. Vertical scale not linear (reproduced with permission of the Royal Netherlands Academy of Arts and Sciences and of Geluk, 2007, after Van Adrichem Boogaert \& Kouwe, 1994).

the non-mobile rock unit, formed prior to the deposition of the first thick, ductile Zechstein salt, the Zechtsein-2 Halite Member (ZEZ2H) (officially accepted revised and updated Dutch stratigraphic nomenclature from Adrichem Boogaert \& Kouwe, 1993; see Figs 2, 3).

The objective of the present contribution is to show that linked depositional and diagenetic models explain reservoir trends. These can be 'translated' into petrophysical values seen on wire line logs in uncored wells, and in seismic expressions showing these trends in undrilled areas. Thus it is a novel hydrocarbon exploration tool that has been successfully applied to delineated and visualised porosity trends in 3 -D seismic in the Collendoornerveen field.

\section{The 'Basal Zechstein'}

The 'Basal Zechstein Unit' is composed of the ZEZ1 (Werra) Formation and the two lowermost ZEZ2C (Carbonate) and ZEZ2A (Anhydrite) Members (Fig. 1) of the ZEZ2 (Stassfurt) Formation (Figs 2, 3). The unit either overlies Carboniferous strata or the Early Permian Rot- liegend Group. It was formed during the Late Permian in the major intra-cratonic Zechstein Sea (Fig. 4) comprising the Northern and Southern Permian Basins that became flooded after a catastrophic transgression from the Barents Sea (Ziegler, 1990; Taylor, 1998; Glennie et al., 2003). In addition, basin tectonics played a role in achieving the differences in thickness of the various units (Geluk, 2005). The Zechstein Sea was situated in an arid climate at a latitude of some $10^{\circ} \mathrm{N}$, north of the Variscan Mountains. This prevented humid air masses reaching the area from the Tethys Ocean in the south. The Zechstein Sea (Fig. 4) extended some $1600 \mathrm{~km}$ from England in the West to the Baltic region in the East (Ziegler, 1990; Geluk, 2005; Peryt et al., 2010). Widespread cyclic deposition of evaporates took place, controlled by glacio-eustatic events and basin tectonics of different nature.

Five Zechstein cycles have been identified in The Netherlands (Fig. 3); transgressions mark their bases. In the lower cycles, i.e. the Z1 (Werra), Z2 (Stassfurt) and Z3 (Leine) Formations, normal-marine conditions prevailed throughout the Southern Permian Basin and clastic influx was pushed back at the basin margins. 


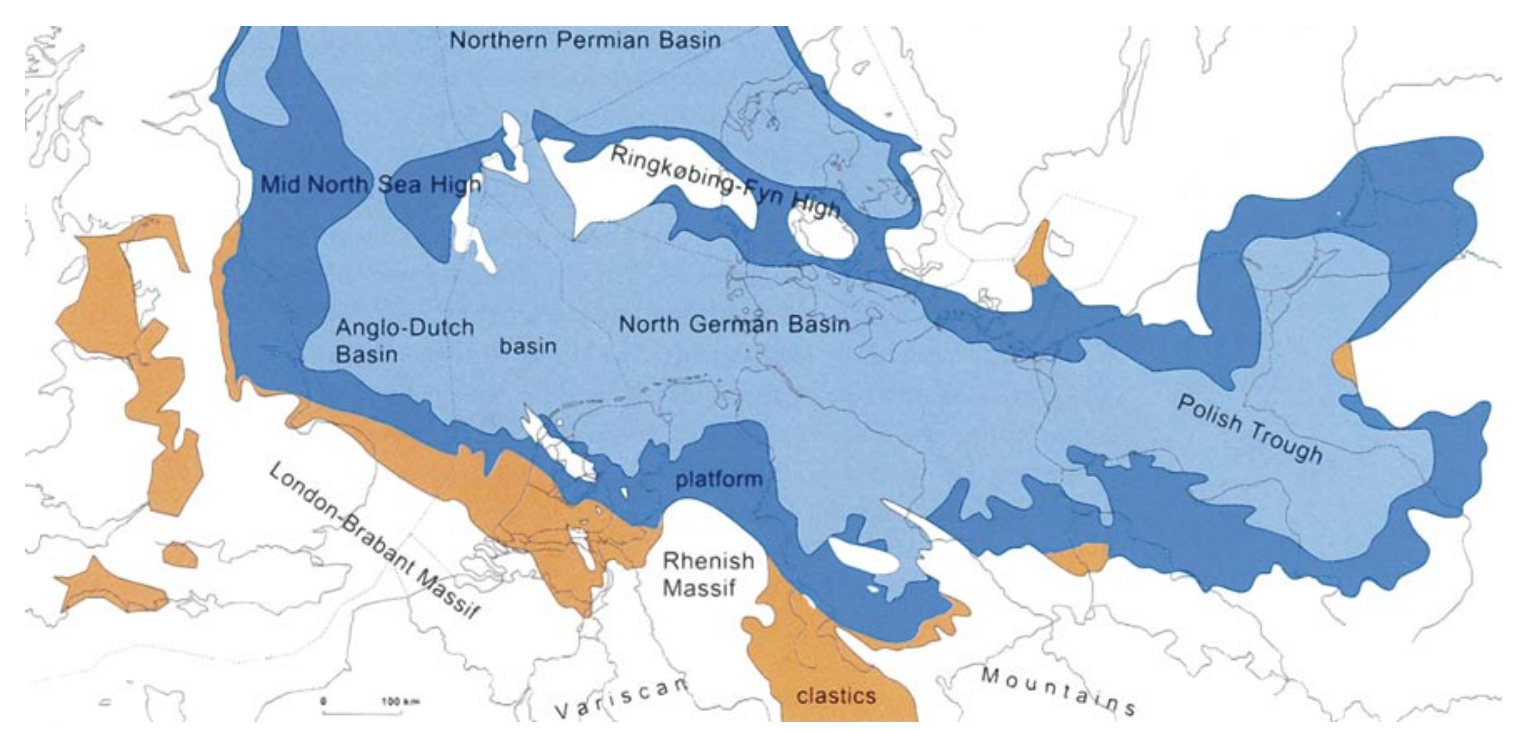

Fig. 4. Facies and present-day distribution of the Zechstein-2 Carbonate Member. The margins of the Southern and the Northern Permian Basins were fringed by carbonate platforms. Contemporaneous clastic sediments were deposited on the landward side of these platforms and in basins in the UK onshore (reproduced with permission of the Royal Netherlands Academy of Arts and Sciences and of Geluk, 2007, after Lokhorst, 1998; Taylor, 1998; and Geluk, 2005).

During the higher cycles, no carbonates were deposited, as the conditions were hypersaline. The depositional thickness of the total Zechstein Group increases from less than $50 \mathrm{~m}$ in the southern Netherlands to over $1200 \mathrm{~m}$ in the northern offshore (Geluk, 2007). On the whole, the carbonates and evaporates accumulated as a series of prograding and aggrading sigmoidally shaped bodies when the facies belts and the area of maximal thickness shifted with time towards the North.

\subsection{The Zechstein 1 (ZEZ1, Werra) Formation}

\subsubsection{The Coppershale ('Kupferschiefer') ZEZ1K Member}

Soon after the Zechstein transgression, nutrient-rich waters, either continental freshwater runoff or upwelling waters caused by trade winds (Brongersma-Sanders, 1971), led to a high organic productivity in the surface waters. Together with high evaporation rates, permanent stagnant bottom-water conditions developed in the deeper parts $(200-300 \mathrm{~m})$ of the basins. There, the finely laminated sediments of the approx. $1 \mathrm{~m}$ thick Coppershale
('Kupferschiefer') Member (ZEZ1K) formed. They are claystones with up to $5 \%$ total organic content (TOC) and locally very rich in copper deposits. Some of these deposits were mined in south-western Poland already in the Middle Ages.

\subsubsection{The Zechstein 1 Carbonate (ZEZ1C) Member}

The Coppershale Member is overlain by the Zechstein 1 Carbonate Member (ZEZ1C), which formed in oxygenated waters; in The Netherlands this took place mainly in marginal areas (Fig. 5A). In the southern and centralwestern parts of The Netherlands, it consisted of marls and carbonates, (up to 200 m thick) in a platform-slope setting, which strongly contrasts with the 8-10 m thick carbonates in the north formed in a starved basin (Taylor, 1998; Geluk et al., 2000; Geluk, 2006). The shallowwater facies yield a rich fauna of close affinity to the Arctic faunal province (Hollingworth \& Pettigrew, 1988). The basal Zechstein sedimentation was mainly controlled by cyclic fluctuations in glacial eustasy, which resulted in progradation of the carbonate platforms, and by inherited relief, especially during and immediately after the initial Zechstein transgression. This palaeogeography and localised tectonics 

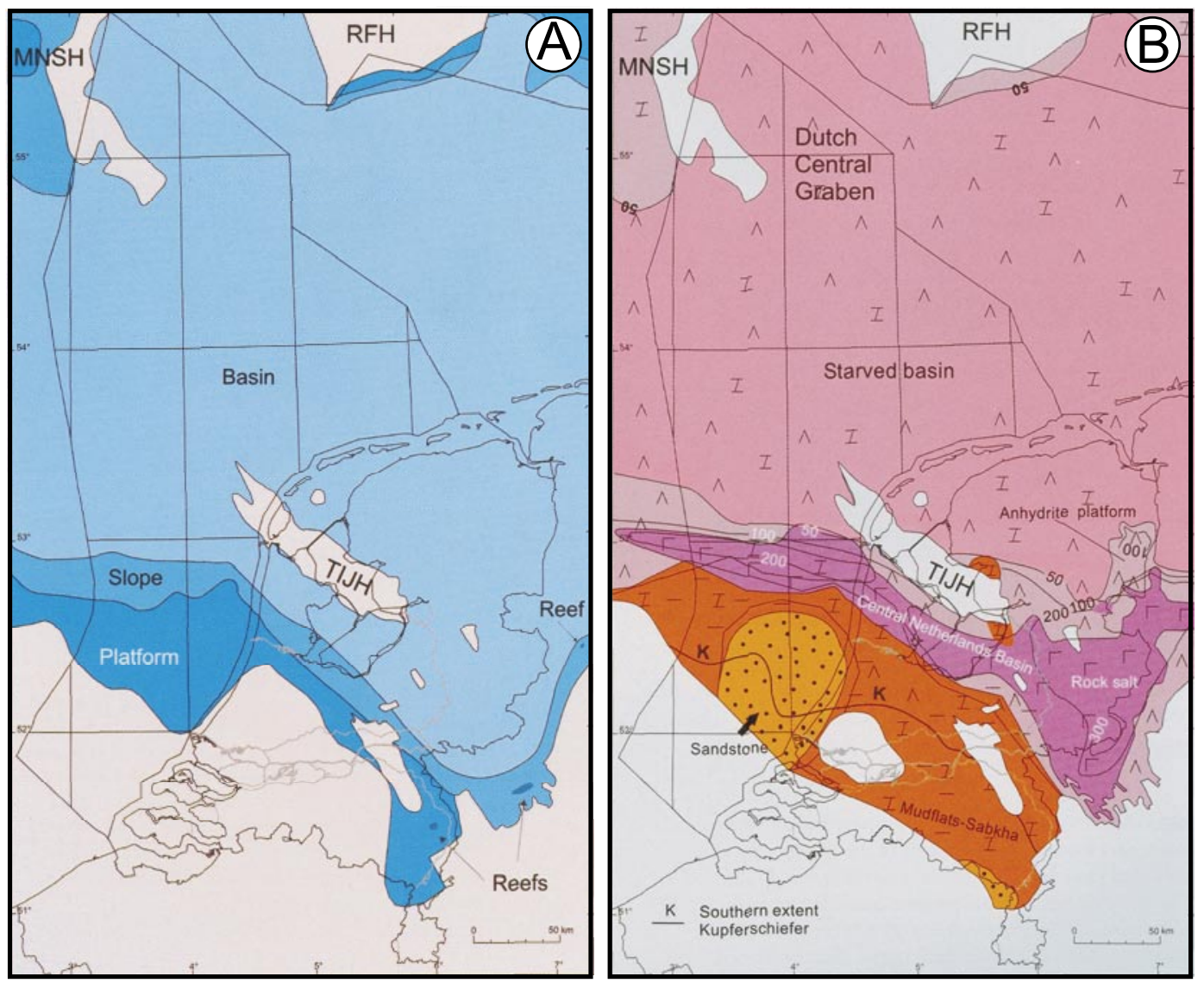

Fig. 5. Facies maps of the ZEZ1 Werra Formation. TIJH: Texel-IJsselmeer High; MNSH: Mid North Sea High; RFH; Ringkøbing-Fyn High.

A: Facies map of ZEZ1C Carbonate Member with carbonate platforms and some reefs fringing the basin and mainly present in the southern and central western Netherlands (reproduced with permission of the Royal Netherlands Academy of Arts and Sciences and of Geluk, 2007, after Johnson et al., 1994, and Geluk, 2000).

B: Facies and isopach map (in metres) of the ZEZ1A Anhydrite Member . Sulfate platforms in the east of The Netherlands may reach thicknesses up to $400 \mathrm{~m}$. They are often formed in conjunction with synsedimentary faulting. Rock salt (up to $300 \mathrm{~m}$ and usually not yet mobile) occurred in the central part of the basin. Sandstones were shed into the basin in the western offshore. In the central part of the basin, carbonates and evaporates were deposited under starved conditions (reproduced with permission of the Royal Netherlands Academy of Arts and Sciences and of Geluk,, after Geluk et al., 1996, 1997; Johnson et al., 1994; and Baldschuhn et al., 2001).

triggered depositional variations in the ZEZ1C belt between England and Poland.

The lower parts of the carbonate-platform sections are mainly composed of carbonate mudstones and wackestones; packstones and grainstones are more common in the upper part. Small carbonate build-ups developed in the southern part of the country, in adjacent parts of Germany and in eastern England, where they developed in a belt varying in width from a few hundred metres to a few kilometres. They consist of boundstones and packstones (Kerkmann, 1969; Peryt, 1978b; Paul, 1980, 1996; Smith, 1981a, b, 1989, 1995; Hollingworth \& Tucker, 1987). The water depth during reef growth is estimated as less than 20 $\mathrm{m}$ close to shore and up to $70 \mathrm{~m}$ farther away (Paul, 2005).

\subsubsection{The Zechstein 1 Anhydrite (ZEZ1A) Member}

The ZEZIC Carbonate Member grades upwards into the (ZEZ1A Anhydrite Member. Under the prevailing hot arid conditions, evaporation was intense. This triggered gypsum precipitation close to the surface of the sea. The accumulation rates of the gypsum crystals greatly exceeded the overall eustatic fluctuations. In the shallow-water areas, gypsum accumulated rapidly and built up to sea 
level. Selenite gypsum is indicative of shallowwater deposition, nodular anhydrite to occasional erosion and exposure. However, sulphate-reducing bacteria proliferated around the chemocline, the transition from the oxic upper water layer to the anoxic deeper waters, which occurred in the Zechstein Sea at some 15 $\mathrm{m}$ water depth (Fig. 6). Gypsum crystals, precipitating in the swallow-water zone, sank to the chemocline and were effectively consumed there by sulfate-reducing bacteria. Thus the areas where the sea floor extended below the chemocline received little or no gypsum.

The marked lateral variation in rates of gypsum deposition between the shallow-water and the starved basin areas resulted in a basin relief up to $400 \mathrm{~m}$ (Fig. 5B). The facies to the South that formed at or around mean sea level within an extensive shallow-water and sabkha environment continued despite the ongoing overall subsidence. Over a distance of 2-3 km down-slope, this facies changed into basinal facies with depositional rates of virtually nil. During the period of gypsum deposition, the described profile was progressively enhanced and the platform top stood some 250-300 m above the adjacent basin areas toward the end of the development of the ZEZ1 Formation.

The more than $150 \mathrm{~m}$ thick sequences that now make the sulfate platforms (Fig. 3), have steep slopes with graded bedding and slopefailure features. Local breccias occur, as well as (dis)solutions. After the sulfate deposition had come to an end, the remaining basins were filled with halite. In The Netherlands this usu- ally happened in peripheral sub-basins away from the main basin (Fig. 5B).

\subsection{The Zechstein 2 (ZEZ2) Stassfurt Formation}

The second Zechstein transgression did not reach as far southwards (Fig. 7A) as the Z1 transgression (Fig. 5A). The ZEZ2 Stassfurt Formation comprises a basal Carbonate Member (ZEZ2C), also called the 'main dolomite', followed by the basal Anhydrite Member (ZEZ2A) which ends the informal 'Zechstein Basal Unit' as used here.

The next member, the ZEZ2H (the Halite Member), is no longer considered to form part of the 'Basal Zechstein Unit' because of its mobile nature and diapirism. Prior to the main dolomite deposition, the sea level could have fallen $100-150 \mathrm{~m}$ as a result of which the outer parts of the basin became exposed and karstified. The next sea-level rise (possibly $70 \mathrm{~m}$ ) resulted in flooding of the carbonate platforms. Coastal and platform-edge ooidal bars developed and prograded. The platform surface was a complex of peloidal, bioclastic, pisolithic packstones and grainstones, alternating with finely laminated wackestones (Clark, 1986; Van der Baan, 1990). Landwards the platform passed into a sabkha facies with salinas. Ooidal and pisoidal bars developed at the edges, as well as small stromatolitic reefs. When the sea level fell towards the end of accumulation of the main dolomite, erosion and karstifica-

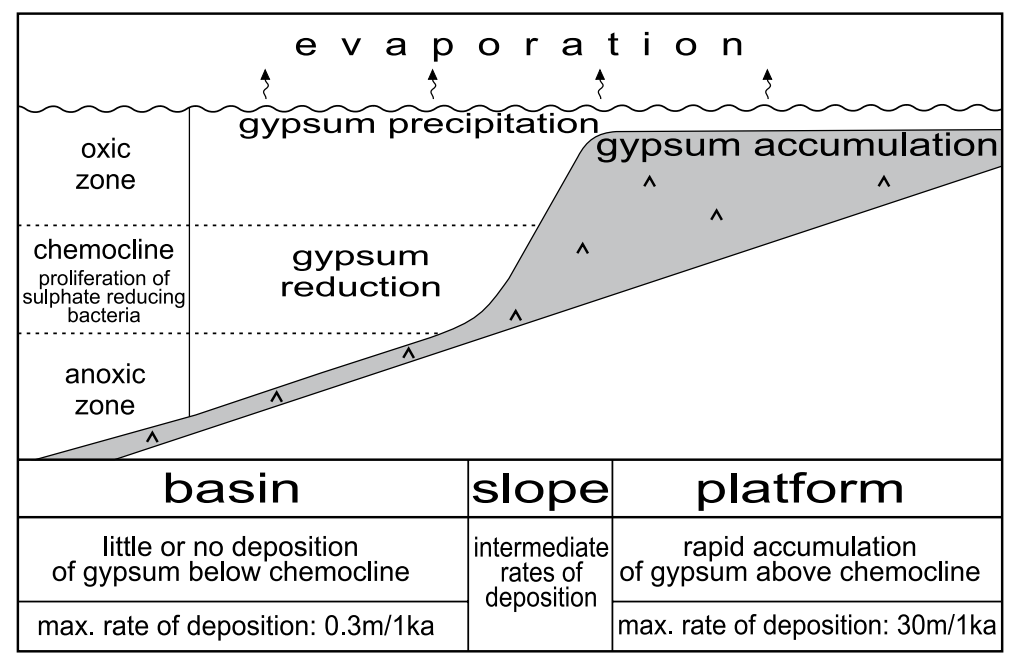

Fig. 6. Development of the sulfate platform in the ZEZ1A Anhydrite Member in the NE Netherlands ((reproduced, with permission from Springer Verlag, from Van de Sande et al., 1996, after Van der Baan, 1990). 

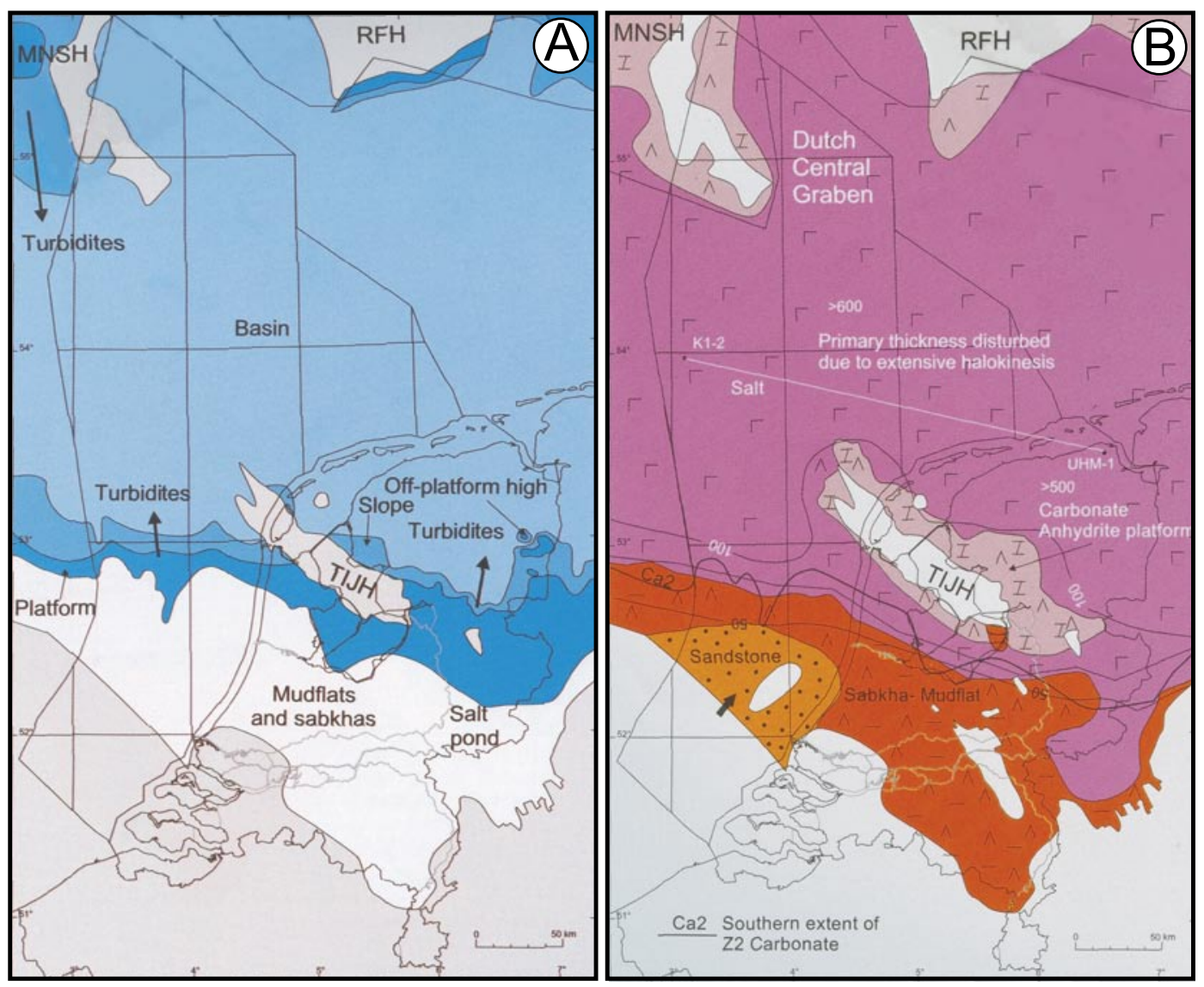

Fig. 7. Facies maps of platforms. TIJH = Texel-IJsselmeer High; MNSH = Mid North Sea High; RFH = Ringkøbing-Fyn High.

A: Facies map of the ZEZ2C Carbonate Member with well-developed carbonate platforms and some off-platform highs in the eastern Netherlands. The basin deposits comprise organic-rich carbonates. Turbidites were shed from the platforms into the basin (reproduced with permission of the Royal Netherlands Academy of Arts and Sciences and of Geluk, after Johnson et al., 1994, and Geluk, 2000).

B: Facies and isopach map (in metres) of the ZEZ2A + ZEZ2C combined. In the carbonate-sulfate platforms, three facies realms are recognised: platform, slope and basin (see Fig. 8). The basin deposits are 8-12 m thick, dark-coloured, bituminous, finely laminated carbonates with source-rock potential and TOC up to $1.2 \%$. In the slope facies (up to $200 \mathrm{~m}$ thick), slumps and turbidites occur, and the platform facies are complexes of oolitic, pelletoidal, bioclastic and pisolithic pack- and grainstones and finely laminated wackestones. Further away in the basin, salt occurs with thicknesses of up to $600 \mathrm{~m}$. As this is ductile and mobile, it is no longer part of the' Basal Zechstein Unit' as defined here (from Geluk, 2007, after Johnson et al., 1994, Geluk et al, 1996, 1997; and Baldschuhn et al., 2001).

tion resulted. During the following flooding, anhydrite was deposited.

Beyond the platform area, a slope with a steep proximal and a less steep distal part occurred. The proximal part was characterised by slumps, slides and calcarenitic turbidites; these grade into pale-coloured calcitic and dolomitic mudstones in the distal part, occasionally surpassing a thickness of $200 \mathrm{~m}$ in the eastern Netherlands. In a number of sub-facies towards the basin floor, the amount of organic material increases and a dark coloured, organic- rich (fetid) carbonate has some source rock poten- tial. The main dolomite unit may reach locally a thickness of $120 \mathrm{~m}$. Detailed 3-D seismic data have revealed complex platform outlines, isolated off-platform highs and intra-platform basins (Van de Sande et al., 1996). The facies distribution of the ZEZ2C Carbonate Member was largely controlled by the palaeo-relief of the ZEZ1A Anhydrite Member that formed a platform (Figs 5B, 6 and 8).

Extensive sedimentological, diagenetic and re-evaluated core data as presented here led to a depositional model to which now a diagenetic model is connected (Van der Baan, 1990; 


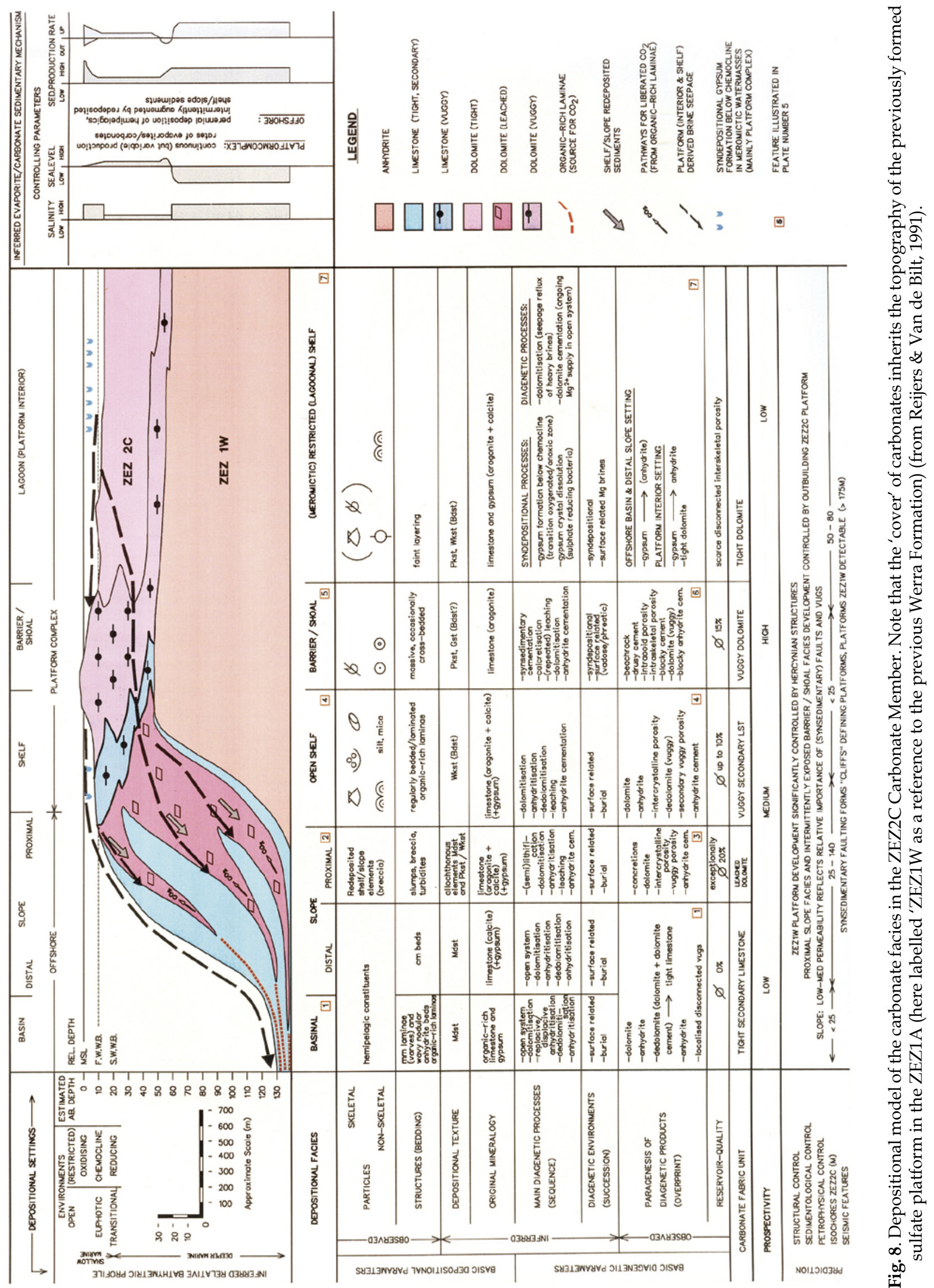



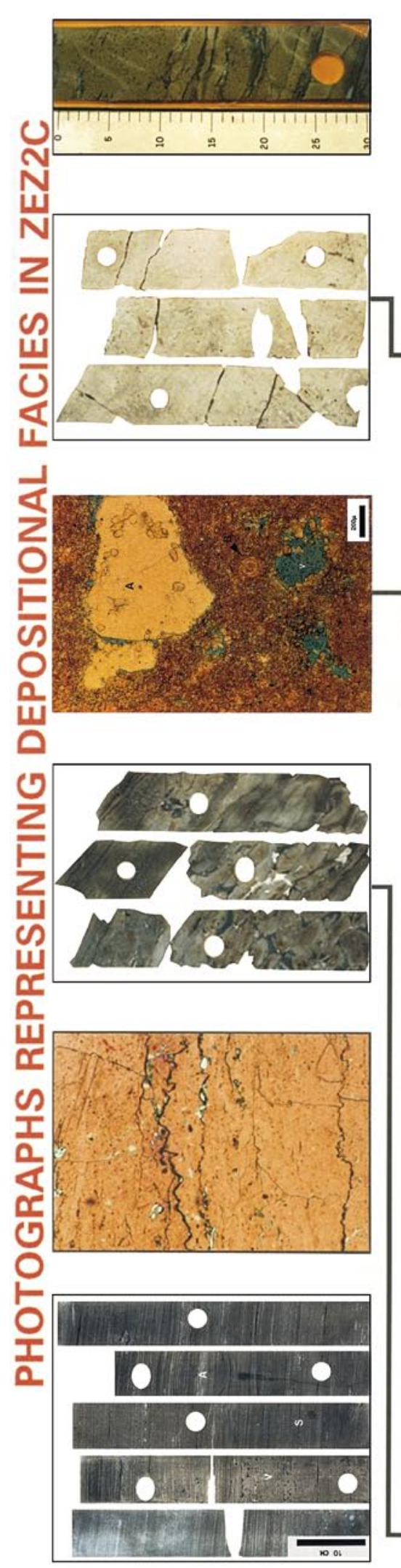

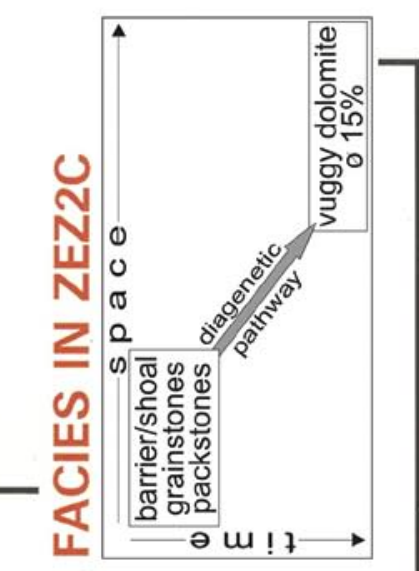

$\frac{1}{\mathrm{C}}$

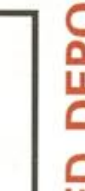

붕
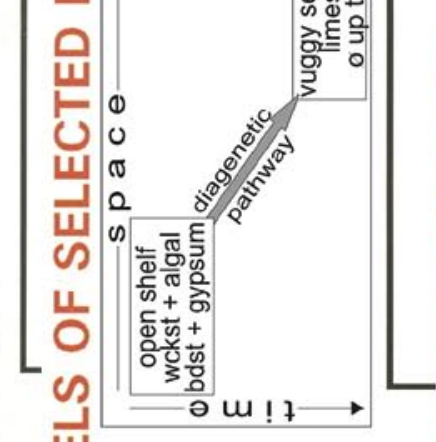

แ1

ํํㄹ

는

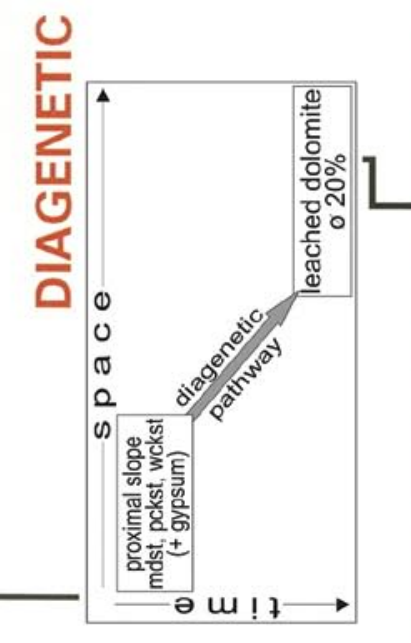

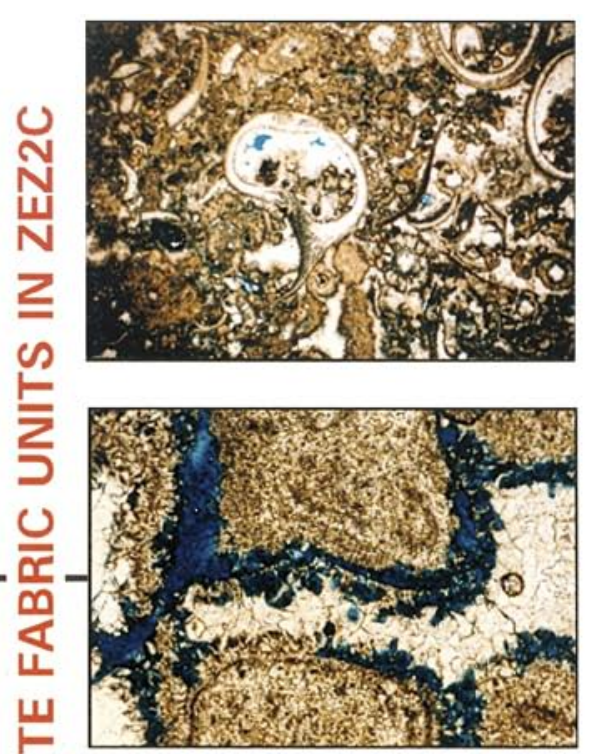

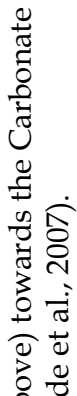

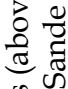

. $\mathscr{C}^{\circ} \frac{0}{0}$

胥

శี

:

造

0

西

$\stackrel{\pi}{\circ}$

है

क्ष

녕

里.

.

हु

范

密䨔

훙

.$\frac{\pi}{5}$

$\infty$

is

近氖

迅.

$\sum$

흘

융

出

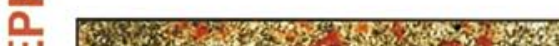

ш

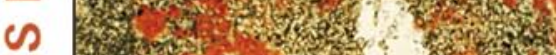

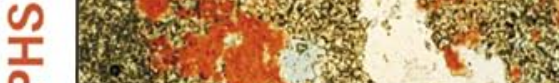

1.

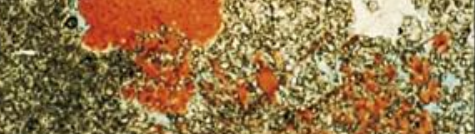

0 Hor

우 अ

다의

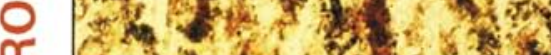

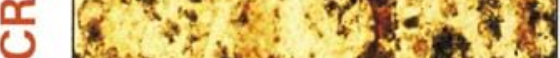

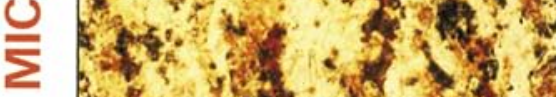

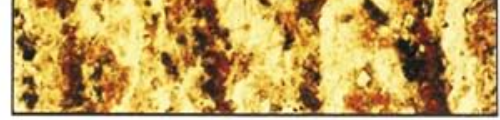

定

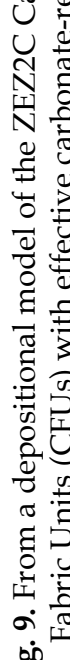


Van de Sande et al., 1996). This clarifies the porosity/permeability distribution in the ZEZ2C Carbonate Member, which was reflected on seismic response and thus in this part of the basin significantly contributed to establishing predictable porosity/permeability trends in potential reservoir rocks.

\section{Depositional facies}

Carbonates and evaporates precipitate from dissolved minerals through abiological or biological mechanisms. The sediments in the evaporite/carbonate Zechstein Group result from both mechanisms: they form abiotic evaporates and largely (but not exclusively) biologically precipitated carbonates. The interplay between abiotic and biotic processes results in a surprising variety of depositional facies (Fig. 8). Each reflects a specific precipitation mechanism. Schlager (2005) introduced the concept of 'carbonate factories' and divided such carbonates into: (1) C-carbonates, formed in cool water, (2) M-carbonates with micrite/ microbes/mud mounds, and (3) T-carbonates formed in the tropics and in the top layers of the sea. Clearly, the carbonate platform/slope facies of the ZEZ2C Carbonate Member be- longs to the T-carbonate factory. However, the basin-bottom facies with substantial amounts of organic material are less easily to be classified, and the evaporites of the ZEZ1A Anhydrite and the ZEZ2A Anhydrite Members, all part of the 'Basal Zechstein Unit', defy classification in Schlager's system.

The present contribution aims at the prediction of porosity trends in the ZEZ2C Carbonate Member. Evaporates are therefore from here on left apart, and the T-carbonate factory concept is used to recognise the wide variety of carbonate platform sub-facies (Fig. 8).

Petrographic porosity/permeability studies have shown that some of the Zechstein carbonates have a characteristic diagenetic overprint creating/occluding additional diagenetic porosity. Thus, initial depositional facies with a depositional porosity are step-by-step changed into 'carbonate units with a texturerelated porosity of a depositional and diagenetic origin', also called 'Carbonate Fabric Units' (CFUs), that turn the carbonates into potential reservoir rocks (Reijers \& Bartok, 1977, 1985). By plotting such porosity/permeability-creating/occluding diagenetic products in a timespace diagram, the 'diagenetic pathway' from a depositional facies to a CFU or carbonate reservoir becomes apparent (Fig. 10). This has

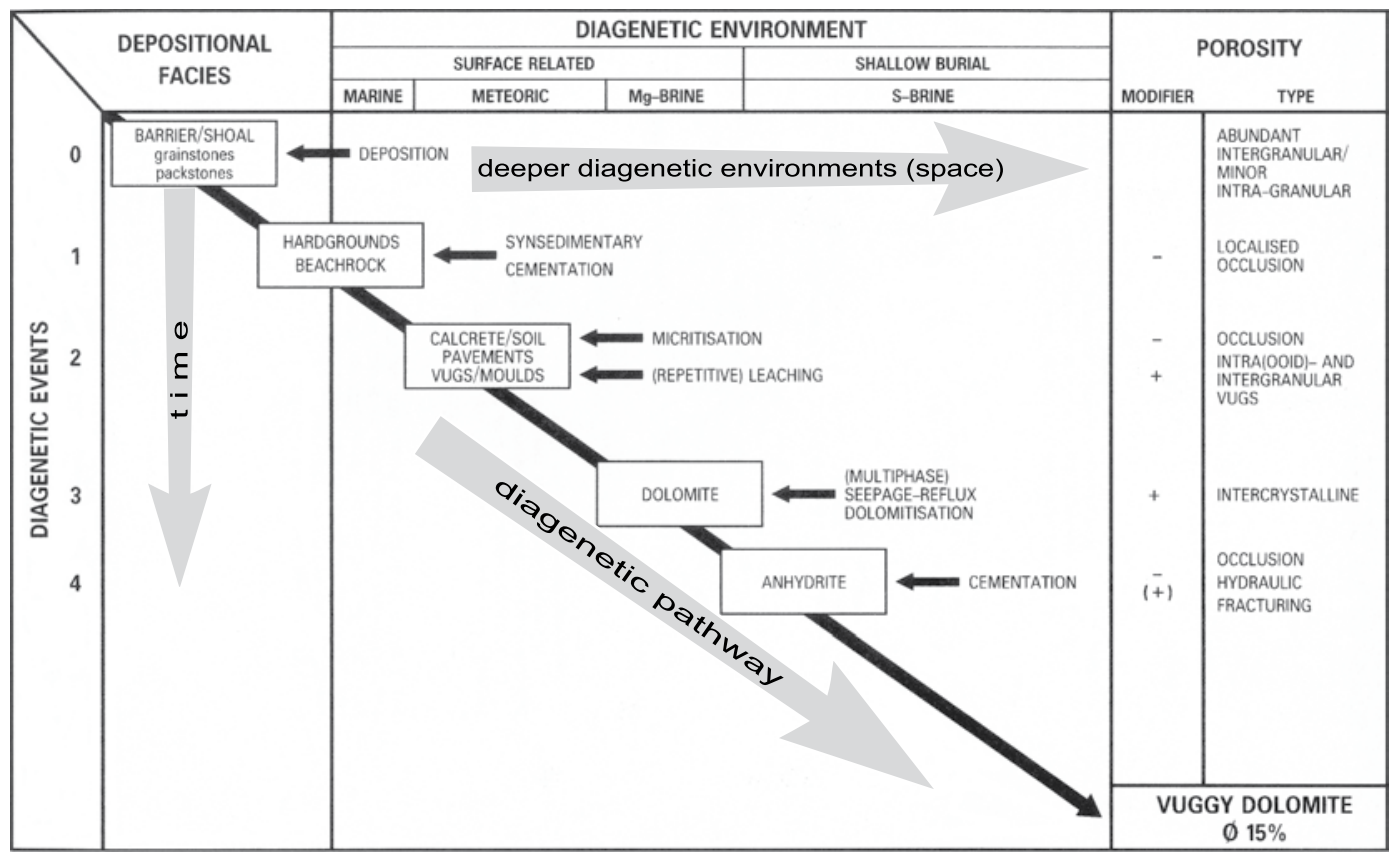

Fig. 10. Diagenetic model for the 'barrier/shoal pack- to grainstones' (from Reijers \& Van de Bilt, 1991). 
Table 1. Depositional facies with their characteristic CFUs.

\begin{tabular}{ccc}
\hline Environment & Depositional facies & Diagenetic cfu \\
\hline data from & Van der Baan & Reijers \\
deep marine & basinal & tight secondary limestone \\
& slope & leached dolomite $\left(^{*}\right)$ \\
shallow marine & open shelf & vuggy secondary limestone $\left(^{*}\right)$ \\
& barrier $/$ shoal & vuggy dolomite $\left(^{*}\right)$ \\
& lagoon & tight dolomite \\
\hline
\end{tabular}

Note: CFUs marked $\left(^{*}\right)$ are shown in detail in Figs 9, 13, 14, 15, 19 and Plates 2, 3, 4, 5, 6.

Table 2. Stable-isotope values related to the depositional/diagenetic environment/CFU of ZeZ2C Carbonate Member samples. For confidentiality reasons, the wells are coded with a letter (if just outside the present study area) or a number (if positioned inside the present study area).

\begin{tabular}{|c|c|c|c|c|c|}
\hline Well & Depth (m) & $\Delta 13 c(\% o p d b)$ & $\Delta 180(\% о p d b)$ & Mineralogy & Cfu \\
\hline 18 & 4404.30 & 6.37 & 2.09 & dolomite & barrier/shoal \\
\hline 18 & 4407.95 & 6.44 & 2.15 & dolomite & barrier/shoal \\
\hline 18 & 4430.90 & 6.47 & 1.29 & dolomite & barrier/shoal \\
\hline 18 & 4430.90 & 6.25 & 0.78 & dolomite & barrier/shoal \\
\hline 18 & 4444.30 & 6.55 & 1.27 & dolomite & open shelf \\
\hline 18 & 444.60 & 6.58 & 1.35 & dolomite & open shelf \\
\hline A & 3864.10 & 5.73 & 0.91 & dolomite & barrier/shoal \\
\hline A & 3864.40 & 5.90 & 0.92 & dolomite & barrier/shoal \\
\hline A & 3885.20 & 6.32 & 1.29 & dolomite & barrier/shoal \\
\hline A & 3885.50 & 6.24 & 1.07 & dolomite & barrier/shoal \\
\hline $\mathrm{B}$ & 4210.60 & 5.96 & -2.11 & dolomite & barrier/shoal \\
\hline B & 4210.90 & 6.12 & -1.46 & dolomite & barrier/shoal \\
\hline B & 4213.60 & 6.55 & 0.54 & dolomite & barrier/shoal \\
\hline B & 4214.50 & 6.16 & -0.69 & dolomite & barrier/shoal \\
\hline $\mathrm{C}$ & 2386.60 & 2.52 & 0.52 & dolomite & barrier/shoal/karst \\
\hline $\mathrm{C}$ & 2386.00 & 2.53 & 0.30 & dolomite & barrier/shoal/karst \\
\hline $\mathrm{C}$ & 2397.35 & -17.17 & -3.54 & limestone & barrier/shoal/karst \\
\hline $\mathrm{C}$ & 2398.25 & -14.21 & -3.96 & limestone & barrier/shoal/karst \\
\hline $\mathrm{D}$ & 3055.70 & 6.67 & 0.07 & dolomite & barrier/shoal \\
\hline $\mathrm{D}$ & 3055.80 & 6.72 & -0.08 & dolomite & barrier/shoal \\
\hline $\mathrm{D}$ & 3061.70 & 6.42 & -0.35 & dolomite & barrier/shoal \\
\hline $\mathrm{D}$ & 3062.60 & 6.34 & -1.12 & dolomite & barrier/shoal \\
\hline $\mathrm{E}$ & 3507.30 & 6.48 & 0.93 & dolomite & slope \\
\hline $\mathrm{E}$ & 3508.70 & 6.37 & 1.02 & dolomite & slope \\
\hline 10 & 3106.80 & 6.36 & 0.25 & dolomite & slope \\
\hline 10 & 3108.90 & 6.33 & 1.33 & dolomite & slope \\
\hline 10 & 3126.60 & 6.96 & 3.63 & dolomite & slope \\
\hline 10 & 3129.30 & 5.66 & 3.76 & dolomite & slope \\
\hline $\mathrm{F}$ & 2259.50 & 5.90 & -1.36 & limestone & basin \\
\hline $\mathrm{F}$ & 2261.00 & 5.84 & -0.41 & limestone & basin \\
\hline $\mathrm{F}$ & 2259.50 & 5.90 & -1.36 & limestone & basin \\
\hline $\mathrm{F}$ & 2268.00 & 6.97 & 2.83 & dolomite & basin \\
\hline $\mathrm{F}$ & 2268.50 & 6.61 & 0.88 & dolomite & basin \\
\hline F & 2270.00 & 6.68 & 1.25 & dolomite & basin \\
\hline F & 2271.00 & 6.59 & 0.38 & dolomite & basin \\
\hline
\end{tabular}

been done for the depositional facies with their characteristic CFUs shown in Table 1.
The petrographic studies and 34 measured isotope values (partly by Van der Baan, unpub- 


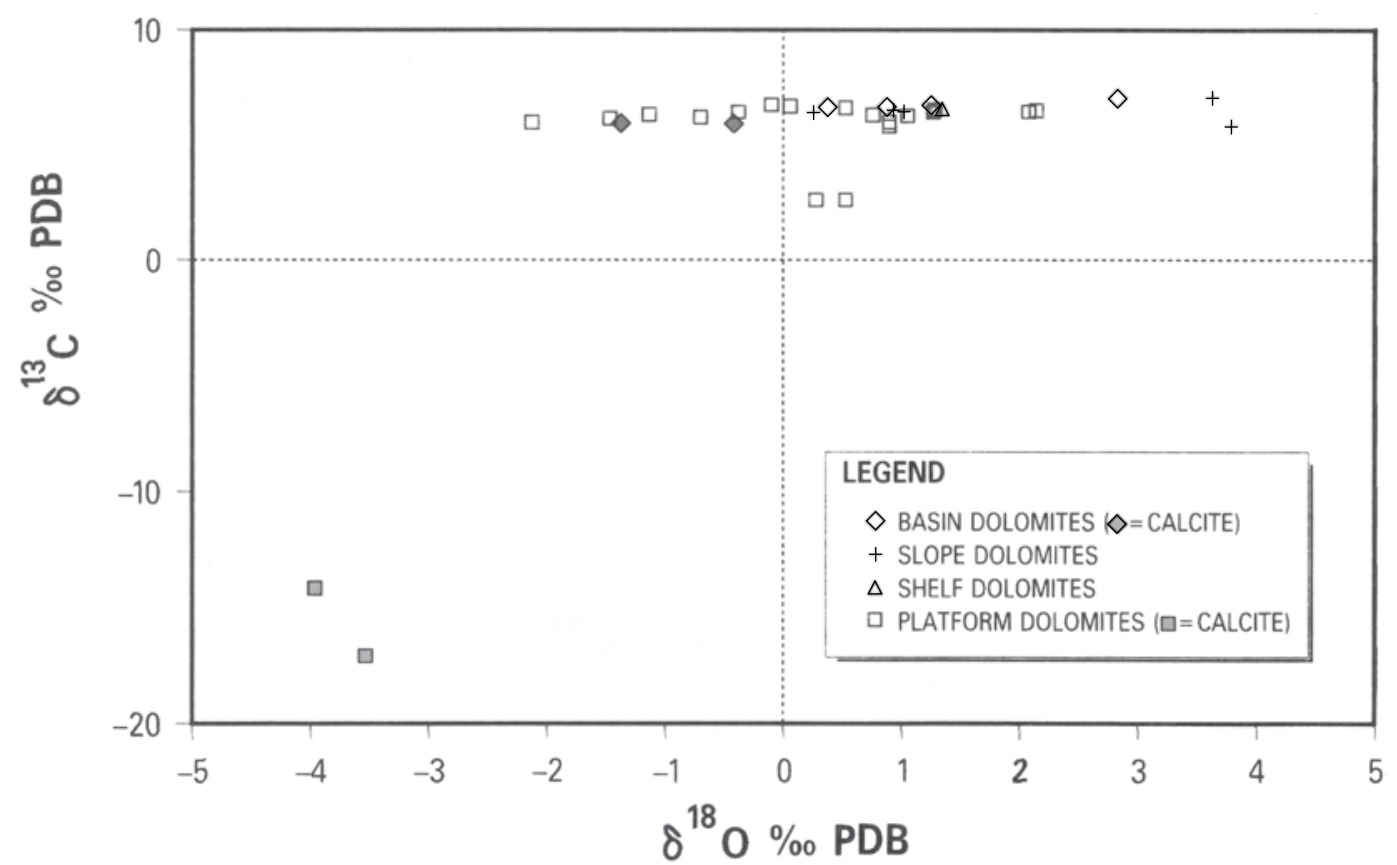

Fig. 11. Carbon vs. oxygen isotope compositions of the Zechstein-2 carbonates (reproduced, with permission, from Springer Verlag, from Van de Sande et al., 2007).

lished; partly by the present author, see Table 2) have been carried out on 8 out of 26 cored wells (cores selected on their suitable position to represent the various facies belts) in the area shown in Figure 11.

Now each facies zone and its complimentary CFU will be briefly discussed, characterised and illustrated with core photographs and microscopic features in thin sections. Brief accompanying explanations and summary diagrams are given of diagenetic paragenesis, inferred diagenetic environments and processes, emphasising the impact on porosity evolution.

\subsection{The facies-CFU spectrum}

\subsubsection{Basin facies}

The basin and distal-slope sediments are composed of hemipelagic mudstones and organic-rich matter concentrated in distinct, undisturbed millimetre-sized laminae (Plate 1A, B). Bioclasts and traces of fossils are absent (Plate 1C, D). Dark organic-rich matter makes the laminae clearly visible (Plate $1 \mathrm{~B}$ ) or is concentrated in seams (marked ' $S$ ' in Plate 1A). The organic matter may represent passageways of overpressurized formation fluids, sometimes associated with dolomite leaching. As a rule, the carbonates are tight secondary limestones, occasionally with disconnected fenestrate vugs. Occasionally, dolomite is present, as well as streaks and patches of nodular anhydrite. Near transitions to thick anhydrite beds, such streaks become more common (Plate 1B). The anhydrites may have formed when relatively warm brines flowed from platform areas down the slopes onto the basin plain. The anhydrite occurs as displacive (apparent from curving of laminae around nodules, Plate 1D) and replacive (apparent from host relicts in nodules, Plate 1D) gypsum growth in the soft carbonates (Richter-Bernburg, 1986). The depositional porosity/permeability of such carbonate mudstones is low.

\subsubsection{The tight secondary limestone CFU}

A summary of the sequence of diagenetic events affecting the basin sediments and the implications on porosity is shown in Figure 12. The CFU resulting from basin/distal-slope facies is a tight secondary limestone. The hemipelagic lime-mudstones occasionally were altered by brines from the platform interior that flowed gravity-driven through inlets in the barrier shoal into the basin where they formed 


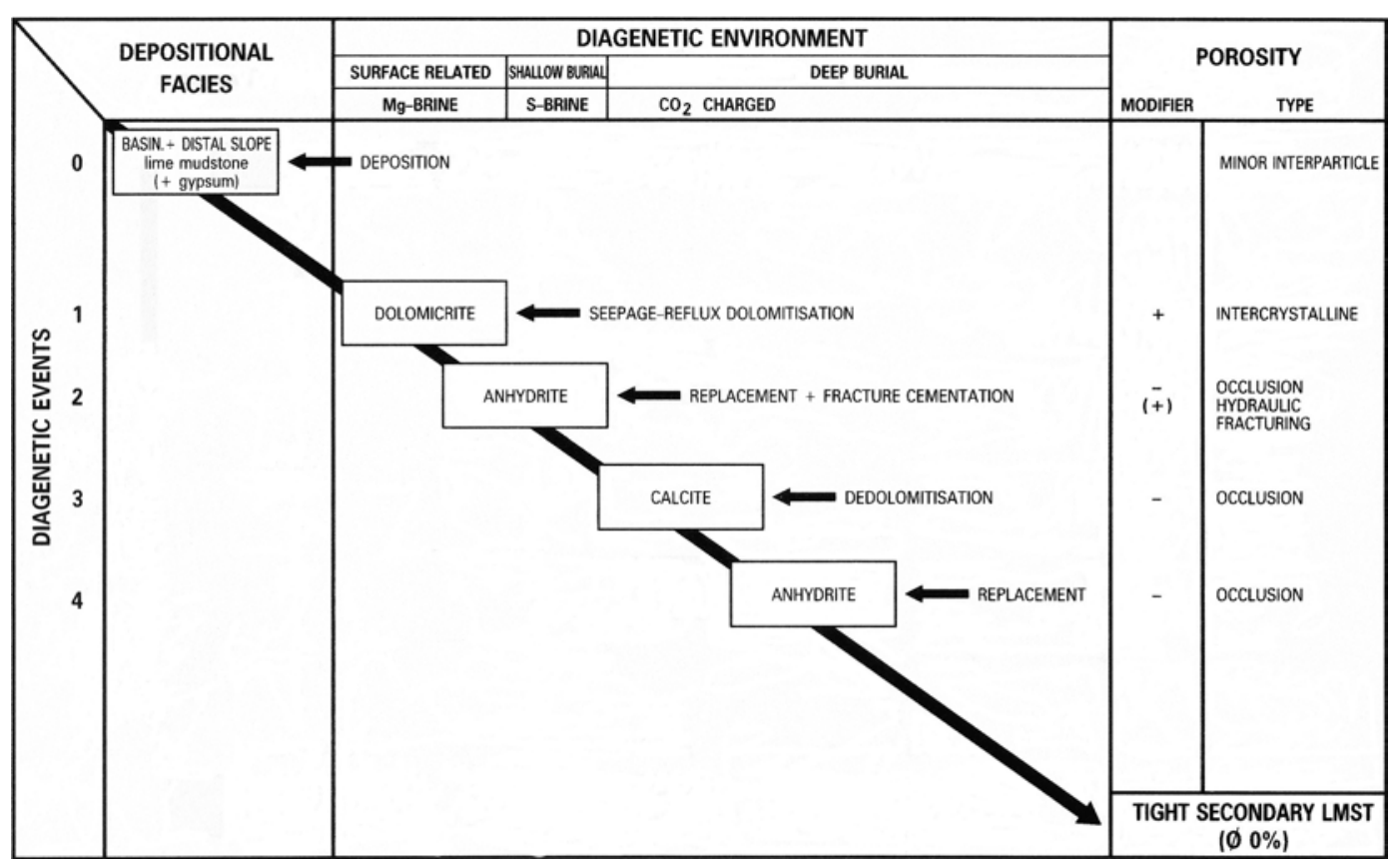

Fig. 12. Diagenetic model for basinal lime mudstones and distal slope carbonates (reproduced, with permission, from Springer Verlag, from Van de Sande et al., 2007).

gypsum crystals and dolomitised the basin lime-mudstones. The dolomitisation process was thus early and it took place synsedimentary in a surface-related environment. Alternatively, dolomitisation occurred slightly later in a shallow-burial environment as a result of downward seeping $\mathrm{Mg}$-rich residual brines when anhydrite or salt deposition commenced in the basin (ZEZ2A and ZEZ2S, respectively).

High $\delta^{18} \mathrm{O}$ and $\delta^{13} \mathrm{C}$ stable-isotope values measured in basin dolomites, $+6 \%$ o to $+7 \%$ o and 0 to $+3 \%$, respectively, are consistent with an evaporative marine pore-fluid origin (Fig. 11). In a shallow burial environment at slightly elevated temperatures (i.e. $42^{\circ} \mathrm{C}$ ), gypsum from adjacent sulfate formations was converted into anhydrite. In this process, large volumes of overpressurized sulfate-saturated crystal water was released and injected into the carbonates, along (hydraulic) fractures and zones of good permeability:

$$
\underset{\text { gypsum } 100 \text { volumes }}{\mathrm{CaSiO}_{4} \cdot 2 \mathrm{H}_{2} \mathrm{O}} \leftrightarrow \underset{\text { anhydrite } 60 \text { volumes }}{\mathrm{CaSO}_{4}}+\underset{\text { water } 40 \text { volumes }}{2 \mathrm{H}_{2} \mathrm{O}}
$$

This resulted in locally pervasive replacement of the host dolomite by anhydrite either as discrete crystals, or as veins or nodules. Anhydritisation clearly post-dated the dolomitisation, as can be seen from the common dolomite relicts in anhydrite (Plate 1C, D). The bulk of the anhydrite is presumed to have a secondary/replacive origin. The anhydritisation probably continued during burial as a multiphase process. At least two anhydrite phases are recognised: pre- and post-calcite. In the burial diagenetic environment, under more elevated temperature conditions (some 80-100 ${ }^{\circ} \mathrm{C}$ : Van der Baan, 1990), calcitisation took place through incongruent dissolution (Plate 1C). Such dissolution of a mineral with decomposition or reaction in the presence of a liquid, converts one solid phase into another. This process was triggered by $\mathrm{CO}_{2}$ derivation from organic matter by decarboxylation.

\subsubsection{Slope facies}

The slope facies are an alternation of beds of autochthonous grey mm-laminated hemipelagic dolomitised mudstones (Plate $2 \mathrm{~B}$ ) and allochthonous redeposited material from the upper slope/shallow-marine shelf. Locally anhydrite is present in laminae, veins or nodules (Plate 2C). The slope successions immediately adjacent to steep (N-facing, see Fig. 11) platform edges commonly show major slumping and sliding. The redeposited sediments come from the platform as ooids- and pisoids-con- 


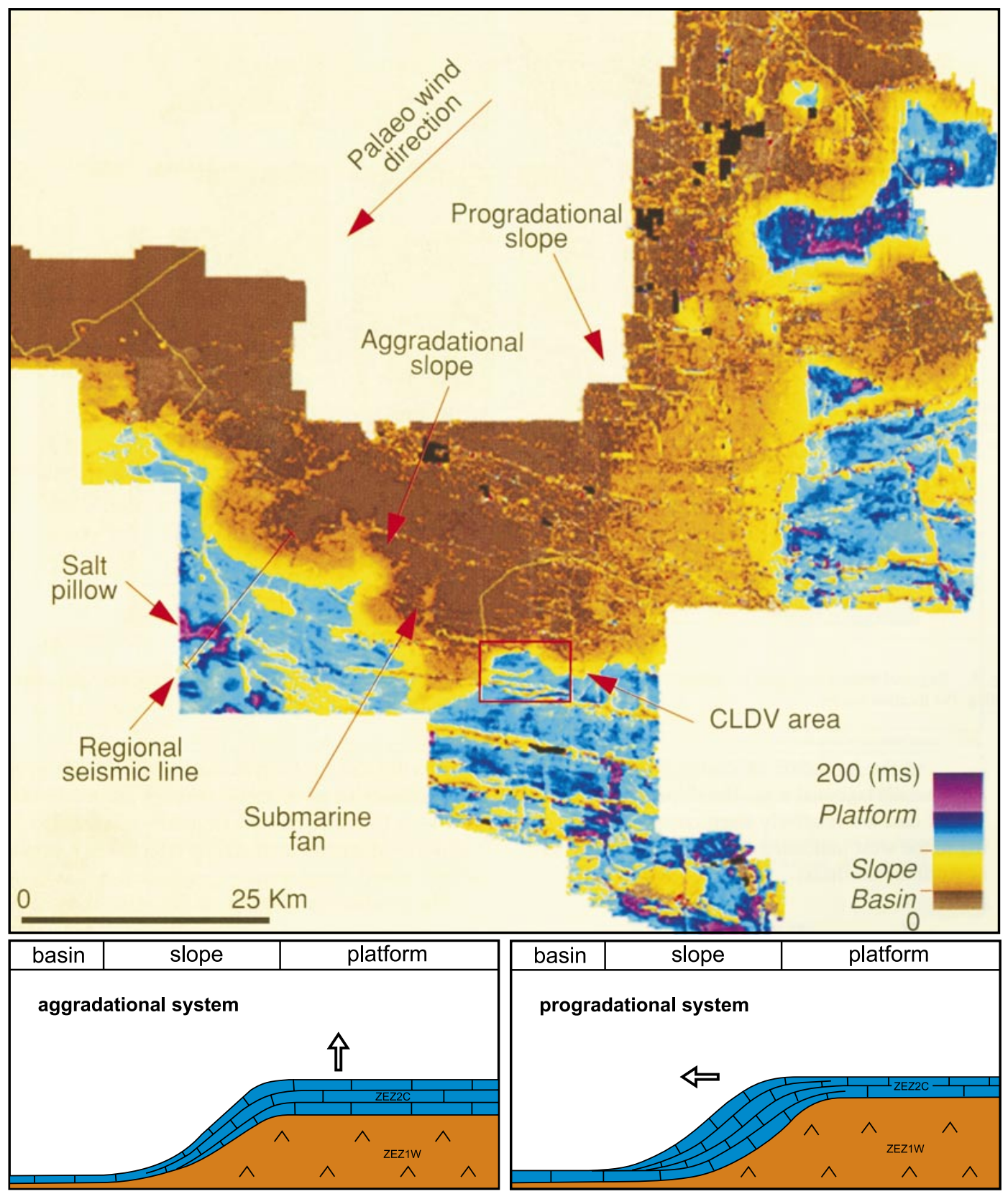

Fig. 13. Time isochore map of the 'Basal Zechstein Unit', derived from 3-D seismic, showing the areas with platform, slope and basin depositional settings. The steep slopes on the north-western side of the platform and the more gentle slopes on the western side reveal a dominantly north-easterly wind direction. Zechstein-1 salt pillars (see Fig. 5B) are visible as very high isochore values. Submarine fan deposits are in the basin close to the platform edge. The CLDVarea is the area of the Collendoornerveen field (map reproduced, with permission from Springer Verlag, from Van de Sande et al., 2007; insets from Reijers \& Van de Bilt, 1991).

taining material in turbidites, fluxoturbidites or debris flows, or from the slope as slumps, slides, conglomeratic debris flows, and $\mathrm{cm}$ dm thick mudstones (Plate 2A, C). Texturally such redeposited sediments are packstones and grainstones. The turbidites locally show graded bedding; by contrast, the debris- flow deposits show brecciated and highly fractured intervals.

The conglomeratic debris-flow units have an appreciable intergranular porosity and permeability, and are therefore adequate pathways for migrating fluids. The dark-brown/ grey matrix of such conglomerates is frequent- 
ly leached and matrix porosities of up to $20 \%$ and permeability of several darcies are common (Plate 2A).

\subsubsection{Leached dolomites CFU}

Figure 14 shows the sequence of diagenetic events and the implications for the porosity of the slope sediments. The leached dolomite CFU is derived from the proximal slope facies. Earlydiagenetic cementation, local synsedimentary concretions and (semi)lithified horizons were formed early on. Dolomitisation of slope sediments can be envisioned by the process of mixing of marine pore water with meteoric water derived from phreatic water lenses extending under the partly/temporarily exposed barriers on the platform. In mixed-water zones, the fluids were undersaturated with respect to $\mathrm{CaCO}_{3}$ and oversaturated with respect to $\mathrm{CaMg}\left(\mathrm{CO}_{3}\right)_{2^{\prime}}$ causing concurrent dolomitisation and leaching (Badiozamai, 1973). This model, however, remains questionable as recent acquired stableisotope data (Table 2) show identical high $\delta^{13} \mathrm{C}$ and $\delta^{18} \mathrm{O}$ values for these dolomites as well as for basin dolomites. The dolomites are expected to exhibit lower and more variable $\delta^{18} \mathrm{O}$ and $\delta_{13} \mathrm{C}$ values, often with a positive covariance (Allen \& Matthew, 1982), or follow the meteoric-water calcite line (Lohmann, 1988).
The measured isotopic values could be better explained by seepage-reflux dolomitisation in which the dolomitisation was caused by downward seeping brines in a shallow-burial diagenetic environment, possibly during deposition of the ZEZ2A Anhydrite Member.

The dolomitisation was followed by anhydritisation in a way similar to the process that affected the basin sediments. Anhydrite in slope sediments occurs also as cement (e.g. in porous redeposited units). The anhydritisation continued during burial, either continuous or in phases.

In a burial diagenetic environment, $\mathrm{CO}_{2}-$ charged pore fluids, generated from decarboxylising organic matter in laminae in the basin sediments, probably migrated along lateral junctions and were introduced into slope sediments. Fluid flow was largely confined to the more permeable redeposited intervals, causing preferential diagenetic alterations in these horizons. The effect of $\mathrm{CO}_{2}$ on dolomite depends on its concentration. Changing amounts of $\mathrm{CO}_{2}$ during diagenesis resulted in a variety of textures (Plates 3C, D). The various carbonate rock types formed in response to differential partial $\mathrm{CO}_{2}$ pressures in pore water are summarized in Figure 15.

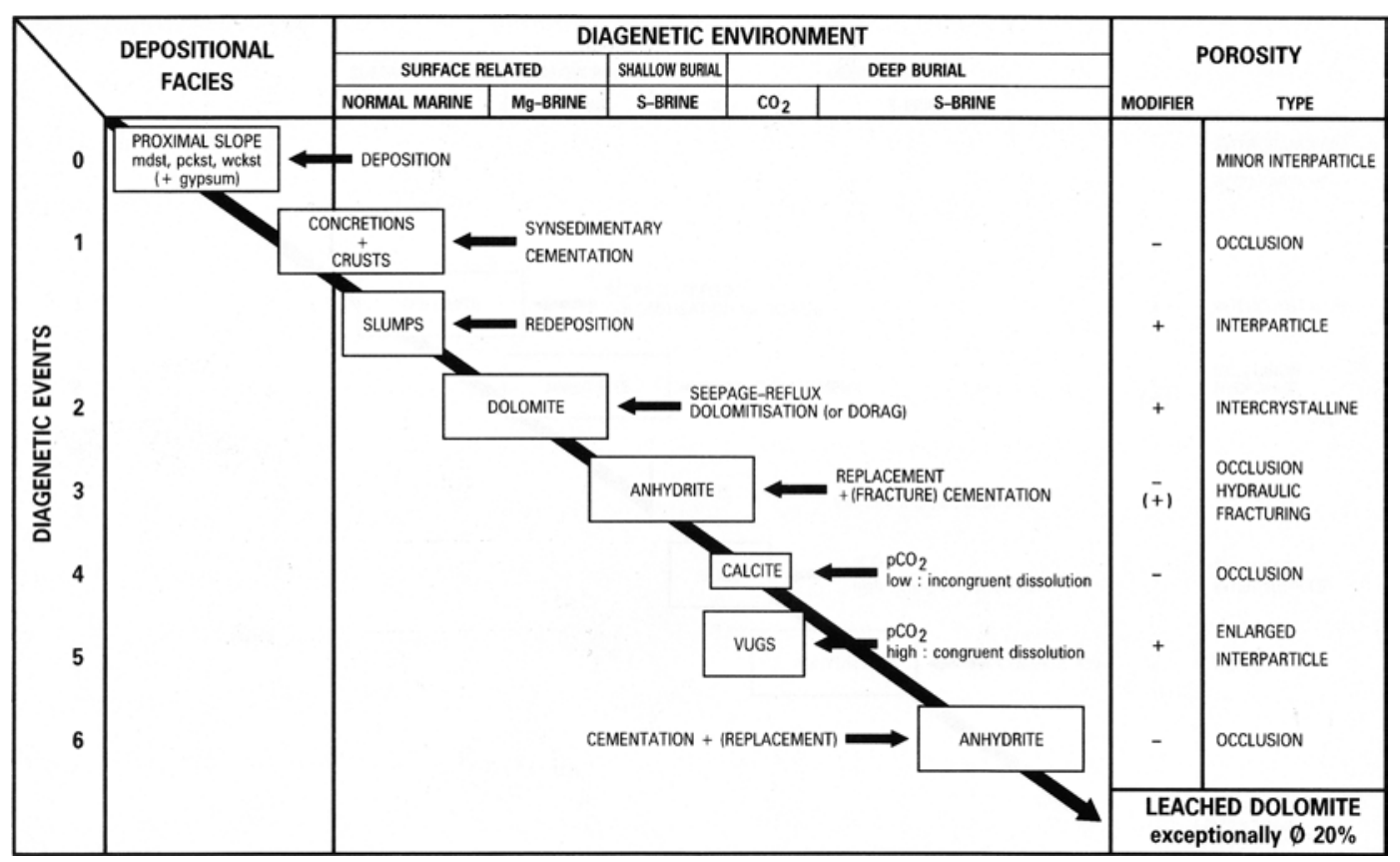

Fig. 14. Diagenetic models for proximal slope carbonates (reproduced, with permission, from Springer Verlag, from Van de Sande et al., 2007). 


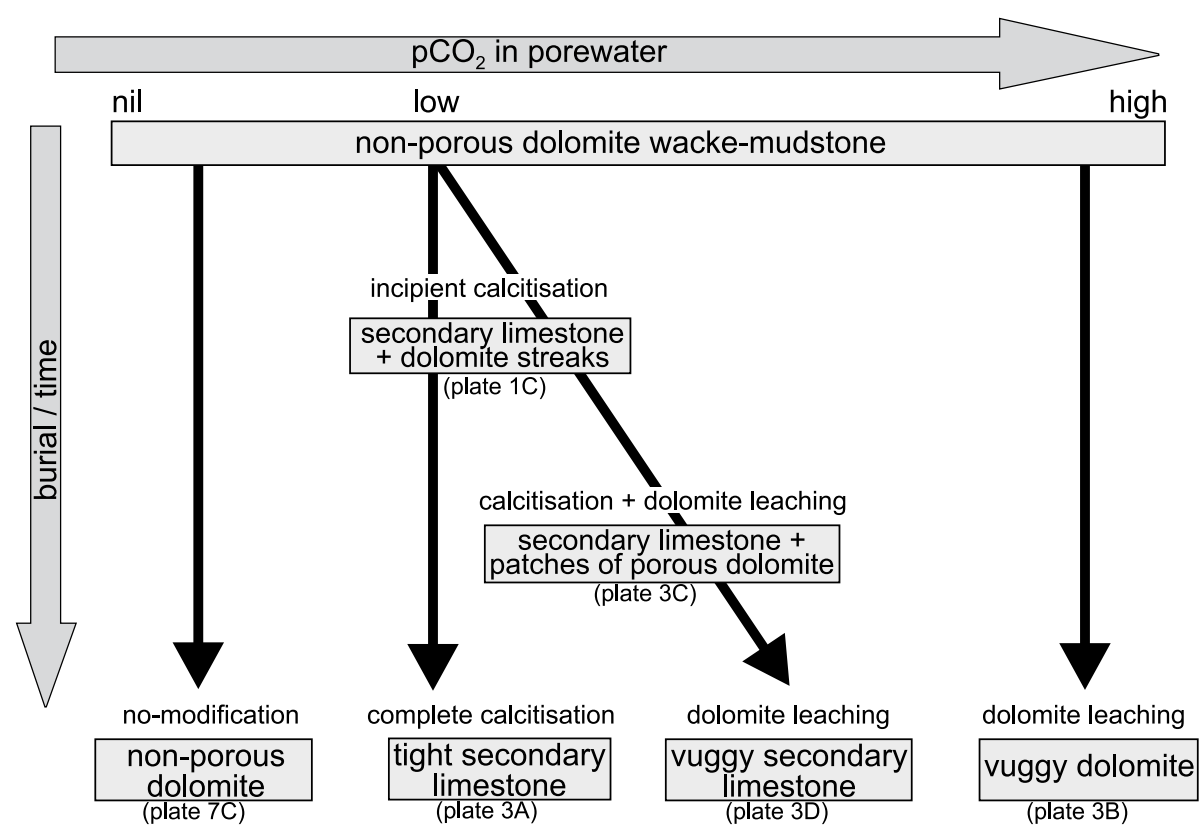

Fig. 15. Genetic scheme of carbonate-rock fabrics related to partial $\mathrm{CO}_{2}$ pore-fluid pressure in a burial environment. A low partial $\mathrm{CO}_{2}$ pressure caused dolomite to decompose and change into calcite (incongruous dissolution, Plate $3 \mathrm{~A})$. However, complete calcite replacement required an extra source for Ca ions. In more permeable zones, the Ca ions for this process are thought to have come from $\mathrm{CaSO}_{4}$-rich water derived from adjacent anhydrite formations, either released by the gypsum-to-anhydrite transformation (Van der Baan, 1990), or by pressure solution. In impermeable zones, however, very few $\mathrm{Ca}$ ions could be brought into the system and calcitisation was restrained by the $\mathrm{Ca}$ ions present, resulting in localised concretionary calcite precipitation. A high partial $\mathrm{CO}_{2}$ pressure caused both dolomite and calcite to be unstable, resulting in (congruent) dolomite leaching (Plate 3B; Tucker \& Wright, 1990). This process can cause significant amounts of (vuggy) pores (secondary non-fabric-selective pores generated by dissolution of large random carbonate constituants leaving large holes or vugs). (reproduced, with permission, from Springer Verlag, from Van de Sande et al., 2007, based on an unpublished note by Van der Baan).

\subsubsection{Open shelf facies}

This facies is intermediate between the barriers/shoal and the slope facies. It reflects part of the shallow-marine environment (depths approx. $10-50 \mathrm{~m}$ ) characterised by a moderately low hydraulic energy as shown by the regular bedded and laminar bedding features, and by open-marine conditions as shown by the skeletal types of the fauna. This facies is not widely distributed in the NE Netherlands where they, due to the prevailing aggradational carbonate build-up mechanisms on windward margins of the carbonate platform, did not develop optimally (Figs 8, 13). Therefore such facies are relatively poorly known.

The sediments are centimetre- to decimetrebedded wackestones (Plate 4A) with bivalve fragments, gastropods, brachiopods, ostracods and nodosariid foraminifers (Plate 4B, C). Algae locally produced non-skeletal algal boundstones. Open-shelf carbonates often contain appreciable amounts of (windblown) quartz silt and mica. Non-fossiliferous carbonates are lithologically comparable to the basin facies. In decreasing order, the shelf facies criteria are: the presence of fossils (Plate $4 \mathrm{~B}, \mathrm{C}$ ), fine clastics and micas, occasional algal boundstones, bioturbation, and a relatively light colour.

\subsubsection{Vuggy secondary limestone CFU}

Figure 16 shows a summary of the sequence of diagenetic events focused on porosity evolution that affected the open-shelf sediments. Fossiliferous wackestones (Plate $4 \mathrm{~B}, \mathrm{C})$ and occasional boundstones were dolomitised, possibly in mixed meteoric-phreatic and marine waters, depending on the postulated actual position of the mixed-water zone. Such dolomitisation approximately coincided with leaching of calcite. Alternatively, dolomitisation resulted from seepage-reflux during deposition of the overlying anhydrite deposits from the ZEZ2A Anhydrite Member. The measured $\delta^{13} \mathrm{C}$ and $\delta^{18} \mathrm{O}$ values of the openshelf dolomites show similar values as the ba- 


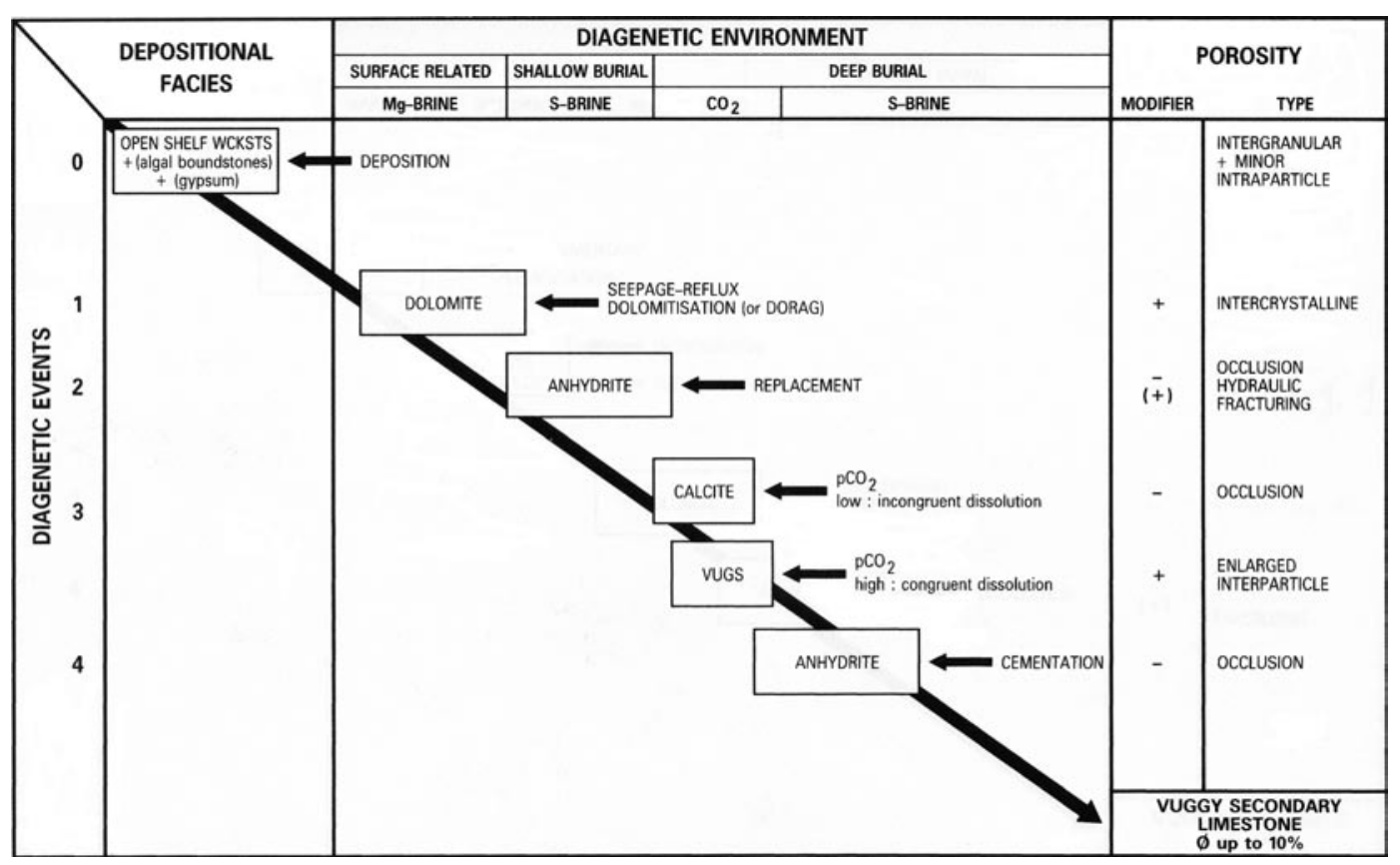

Fig. 16. Diagenetic model for open-shelf wacke- to boundstones (reproduced, with permission from Springer Verlag, from Van de Sande et al., 2007).

sin dolomites (Table 2; Fig. 11). This suggests comparable dolomitisation models both for the basin and the slope dolomites. A 'mixing zone' dolomitisation model (Badiozamani, 1973) seems unlikely for the basin sediments; here a seapage-reflux model associated with overlying anhydrite is the most likely alternative. Under elevated temperature and pressure conditions in the shallow-burial environment, sulfate brines were introduced from the underlying ZEZ1 Anhydrite Member, causing replacement of dolomite by anhydrite (Plate 4C).

Decarboxylation of organic matter from the algal boundstones released $\mathrm{CO}_{2}$ which, depending on the partial $\mathrm{CO}_{2}$ pressure, prompted dedolomitisation and/or leaching. Depending on the relative timing and intensity of these processes, this resulted in alternating beds of tight/leached dolomite and in tight (Plate 4B) and vuggy secondary limestones (Plate $4 \mathrm{C}$ ).

\subsubsection{Barrier/shoal facies}

The barrier/shoal facies are high-energy sediments deposited in a very shallow to intermittently intertidal open-marine environment. Some sediments were submerged and occasionally intertidal, others were subaerially exposed (Fig. 17A).

\subsubsection{Submerged to intertidal deposits (Plate 5A C)}

The predominantly light-coloured grainstones and packstones are composed of ooids, pisoids, occasionally of oncoids, grapestones, intraclasts and bioclasts (Plate 6). The sediments are centimetres to metres thick; they are normally graded from medium to coarse in grain size and they often include gravel-sized intraclasts. Though usually massive, some beds show centimetre-scale parallel wavy bedding (Plate 5A, C) and occasionally planar crossbedding.

Characteristically the clasts are flat to angular/rounded clasts ranging in size from less than a millimetre to several centimetres (Plate $5 \mathrm{~A})$. They are of the above-mentioned rock types, but frequently they also have a diagenetic 'pelleted fabric'. Similar clasts are well known from Shark Bay (Australia), where they develop in the upper intertidal zone with long periods of desiccation interspersed with erosive tidal flooding (Logan, 1974; Van der Baan, 1990). Keystone vugs, vadose compaction and geopetally-filled voids further indicate the partly intertidal origin of the sediments.

\subsubsection{Exposed sediments (Plate 5B, D, E)}

During sea-level low-stands, parts of the barrier/shoal facies were subaerially exposed 


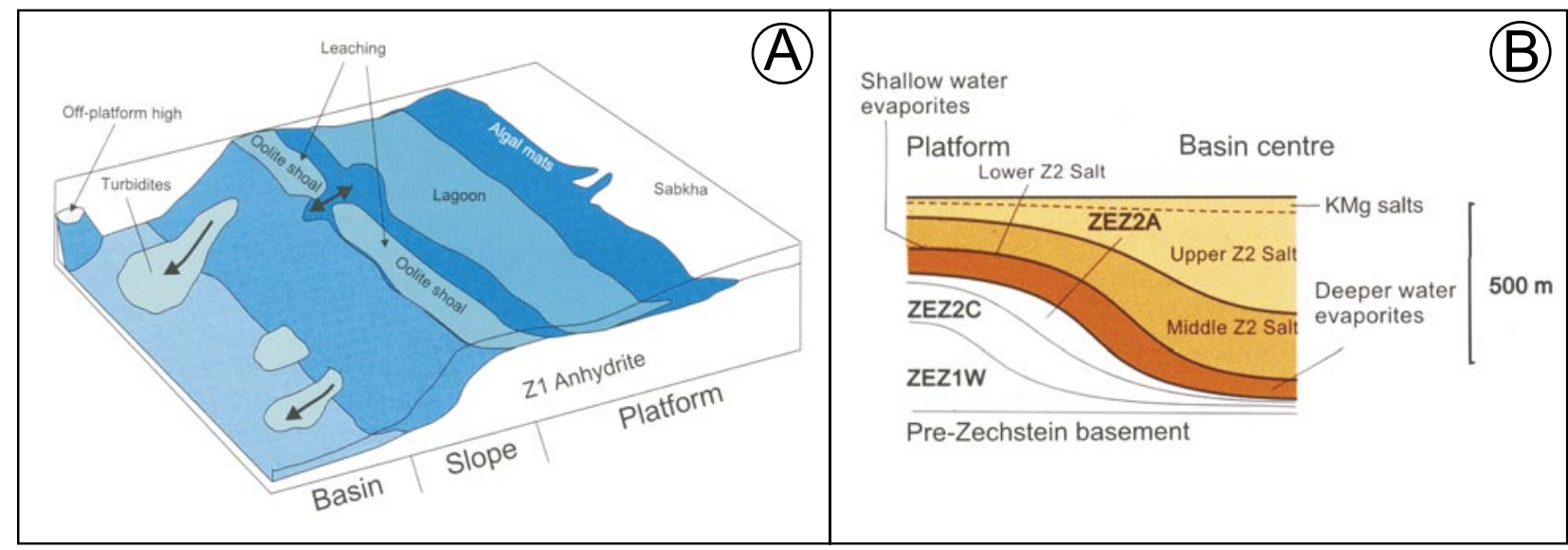

Fig. 17. Characteristics of the ZEZ2C carbonates.

A: 3-D simplified depositional model of the ZEZ2C Carbonate Member (compare with Fig. 8). In the basin, finegrained lime muds were deposited. Near the carbonate slope, distal turbidite deposits occur. On the slope, the finegrained sediments occur mixed with coarser, redeposited platform sediments. The platform facies mosaic includes ooid shoals, lagoonal deposits and scattered algal mats (reproduced, with permission of the Royal Netherlands Academy of Arts and Sciences and of Geluk, 2007, after Geluk et al., 1997).

B: 2-D model of deposition of the ZEZ2A Anhydrite Member and the ZEZ2H (Halite Member), together forming the lower part of the 'Upper Mobile Unit' of the Zechstein Group that overlies the 'Basal Zechstein Unit' (reproduced, with permission of the Royal Netherlands Academy of Arts and Sciences and of Geluk, 2007).

over prolonged periods. Emergence of the shoals to the inter/supratidal zone resulted in algal mats and the development of 1 to 10 centimetre thick lithified crusts forming extensive jointed and brecciated pavements (Plate 5E). Fragments of such pavements ranging in size from granule to large cobbles were transported during storms and formed horizontal or imbricated layers depending on the energy involved in their transport (Plate 5D). Such sediments are assumed to be analogous to the supratidal pavement breccias described from Shark Bay (Logan, 1974). Prolonged subaerial exposure resulted in local calcretisation, characterised by (laminated) crusts of dense carbonates, brecciated and associated with patches of micrite, (rare) vadose pisoids, and intense leaching by meteoric water, giving a mottled appearance (Plate 5B).

The barrier/shoal facies are good reservoir rocks with measured porosities averaging $10-15 \%$. Lithified crusts and calcretes, however, form local permeability barriers that compartmentalise the reservoir interval. The best depositional porosities are expected on the NE windward margins (Fig. 13) of aggradational carbonate platforms where the energy levels were highest. Leeward platform margins with gentle progradational slopes seem to lack a belt of porous carbonates (Van der Baan, 1990).

\subsubsection{The vuggy dolomite CFU}

Figure 10 shows diagenetic events with emphasis on the porosity evolution. Diagenetic modifications converted the barrier/shoal carbonates into the vuggy dolomite CFU reservoir rock. Texturally, these sediments are predominantly clast-supported with large interconnected pores, resulting in a high initial intergranular porosity. The pores were enhanced by early-diagenetic leaching by meteoric water (Plate 6A, F) or (partly) occluded by dolomite (Plate 6B) and anhydrite cement (Plate 6D).

In the submerged zone, syndepositional cements formed locally. The laterally restricted hardgrounds are characterised by isopachous acicular (aragonitic) rim cement fabrics (Plate $6 \mathrm{~B})$. In relatively low-energy settings like intershoal areas, carbonate grains were micritised by algal/fungi boring activity. Micrite rims were the result (Plate $6 \mathrm{C}$ ) and, eventually, complete micritisation of particles (Plate $6 \mathrm{D}$ ).

In the intertidal zone, the sediments were locally cemented and beach rock was formed. This is characterised by an acicular and microcrystalline (aragonitic) rim cement with meniscus and microstalactitic fabrics that often 
became subsequently obscured by later cementation and dolomitisation. Such cements precipitate from formation water drained from the narrow spaces of grains, but held back by capillary forces forming meniscus or pendant cements in between or at the bottom of grains where droplets are held. Volumetrically, hardgrounds and beach rock are of minor importance, but as permeability barriers they can be significant.

During sea-level low-stands, the carbonate sediments were subaerially exposed and entered vadose and phreatic/meteoric diagenetic environments. Prolonged subaerial exposure in barrier/shoal carbonates resulted in calcretes/soils. These were formed by early diagenetic processes involving porosity creation by meteoric-water leaching as well as porosity occlusion by cementation, micritisation and neomorphism. Typical vadose meteoric cements are irregular low-magnesium calcite rims with meniscus and microstalactitic fabrics. Phreatic cements are characterised by equant, blocky cement fabrics. Ideally, calcrete profiles consist of a leached, porous zone, occasionally capped by a hardpan layer with low porosity and a lower zone characterised by low porosity, cementation and neomorphism (Van der Baan, 1990). Petrographically, soil/calcrete diagenetic processes are recognised from such products as patchy, clotted and laminar micrite (crusts) non-tectonic fractures and breccias, circumgranular cracks, soil glaebules (vadoids), rhizoliths (root traces), meniscus cements, vadose compaction features and abundant irregular vuggy pores with occasionally crystal silt (crystal fragments, partly filling a solution void) (Plate 6E, F). Identification of calcrete/ soils remains difficult, however, because most of the above-mentioned features are not exclusive for subaerial exposure surfaces, but can also occur in other diagenetic environments (Esteban \& Klappa, 1983). Generally, the abovementioned processes resulted in significant porosity enhancement with average values of $10-15 \%$. Intragranular (in oolites) and vuggy pores predominate.

The dolomitisation of barriers/shoal sediments was pervasive and resulted in a finely crystalline, anhedral, texture-preserving dolo- mite. Vugs, formed by meteoric-water leaching, with dolomite (rim) cements suggest that dolomitisation postdates leaching. However, the leached dolomite textures suggest a reverse relationship. Possibly, this is the result of several phases of leaching and/or dolomitisation. Multi-phase dolomitisation is also suggested by an unpublished pilot study (Van der Baan, 1987) on cathodoluminescence concerning some dolomite samples with signs of several dolomite generations.

Stabilisation of the carbonate framework by cement must have taken place before significant burial, as evidenced by the common absence of compactional features such as long/ sutured grain contacts (Plate 6). The finely crystalline, texture-preserving dolomite, combined with the close spatial relationship with overlying evaporates, and the pervasive character of dolomitisation suggests a seepage-reflux dolomitisation process (Moore, 1989, 2001). The dolomitisation is likely to have occurred during deposition of the overlying ZEZ2A Anhydrite Member. Stable-isotope values give an average of approximately $1 \%$ o $\delta^{18} \mathrm{O}$ and $6 \%$ o $\delta^{13} \mathrm{C}$ (Table $2)$, which confirms an (evaporative) marine pore-water isotope composition (Fig. 11).

Coarse crystalline anhydrite occurs locally as a pore-filling cement (Plate 6C, D) and as a dolomite-replacive mineral. Its occurrence is probably related to the gypsum-to-anhydrite transformation in the adjacent evaporates. This process involves a $40 \%$ reduction in volume of the solid material (see section 3.1.1.1). However, as the volume of water plus anhydrite is larger than that of gypsum only, $\mathrm{CaSO}_{4}$-saturated water was expelled from the evaporates and injected into the adjacent carbonates, resulting in anhydrite precipitation.

During the Cimmerian tectonic phase, the Zechstein sediments were locally uplifted and partly eroded. The influx of meteoric water, associated with erosion, caused local calcitisation, the formation of karst profiles and collapse breccias. Calcite associated with meteoric water can be distinguished from burial-related dedolomitisation on the basis of stable-isotope signatures. Soil-derived $\mathrm{CO}_{2}$ in meteoric water resulted in negative $\delta^{18} \mathrm{O}$ and $\delta^{13} \mathrm{C}$ values for meteoric calcites, whereas burial-related cal- 
cites show positive $\delta^{13} \mathrm{C}$ and variable $\delta^{18} \mathrm{O}$ values (Table 2).

\subsubsection{Lagoon facies}

The lagoon facies reflect a low-energy, restricted, shallow but locally deep environment (Figs 8, 17). The shallow-lagoon facies consist of wacke/packstones of peloids, shell fragments and gastropods. Locally stromatolites are present. The shallow-lagoon sediments are usually light in colour and show generally faint-to-well developed centimetre to decimetre bedding. Occasionally beds vary in thickness (Plate 7B). The shallow-lagoon sediments with ooid-washover sheets (Fig. 17) were usually submerged, but intercalated intervals with desiccation features and occasionally with soils point to local/temporal subaerial exposure. The deep-lagoon deposits consist of grey to dark-grey mudstones with regular centimetre to decimetre bedding, organic-rich horsetail seams and rare spherical concretions (Plate 7A). Fauna (bivalves and benthonic forams) is rare.

In both the shallow and the deep lagoons, gypsum precipitation from supersaturated brines probably took place subaqueously at the time of deposition during evaporative periods. Erosion surfaces related to the Cimmerian uplift occur predominantly in platform carbonates, particularly near pre-existing highs or at the rim of the Zechstein basin where sedimentation in the Fringe Zechstein Member (Fig. 3) was largely terrestrial or supratidal.

\subsubsection{Tight dolomite $\mathrm{CFU}$}

In Figure 18 the sequence of diagenetic effects is shown, particularly those related to porosity evolution for the open-lagoon facies, resulting in a tight dolomite CFU reservoir. During deposition, the pore fluids in the wacke/packstones were hypersaline, causing syndepositional gypsum precipitation. The depositional porosities of the restricted-lagoon facies were low to moderate, and were further reduced by gypsum precipitation. Syndepositional precipitation of sulfates led to increased $\mathrm{Mg} / \mathrm{Ca}$ ratios of the downward seeping brine, causing syndepositional dolomitisation. Dolomite cement, followed by anhydrite cement (Plate 7C) occluded porosity. The above modi- fications caused rapid porosity destruction, resulting in a tight dolomite CFU with poor reservoir potential.

\section{Fractures in the Zechstein carbonates}

In the ZEZ2C Carbonate Member with some initial matrix porosity, fractures are important in two ways: (1) adding to the porosity (although in a minor way only), and (2) adding significantly to the permeability. As a consequence, fractures may add to hydrocarbon productivity, which makes predicting the occurrence, nature and orientation of fractures desirable. A correlation between fracture parameters and productivity of the matrix porosity is useful only if the nature and predictability of the matrix porosity is understood, as explained and illustrated above.

Now the fracture parameters will be described and illustrated. Fracture parameters are of a genetic, diagenetic and geometric nature. Genetically, coring-induced fractures result from stress releases due to unloading while the cores are brought to the surface (Plate 8A). They will not be considered here.

Natural fractures are subdivided, depending on the importance of shear displacement, into extensional, shear and hybrid (= dilatational shear) fractures (Plate 8A). Amongst extensional fractures, fractures cutting across and fractures following the boundaries of individual grains/crystals can be distinguished. The former group reflects advanced matrix lithification, perhaps following burial, and such fractures may reflect tectonic movements. The latter group reflects incompletely cemented matrices, and fractures formed under such conditions may have been subject to reduced loading or result from dehydration, both pointing to fracture formation, possibly in a surface-related diagenetic environment. Fractures cross-cutting grains/crystals have usually sharp edges, and may be cemented or partly open, whereas crumbly fractures follow particle/crustal boundaries and are cemented.

Hairline fractures (Plate 8B), or capillary fractures, are characterised by non- separat- 


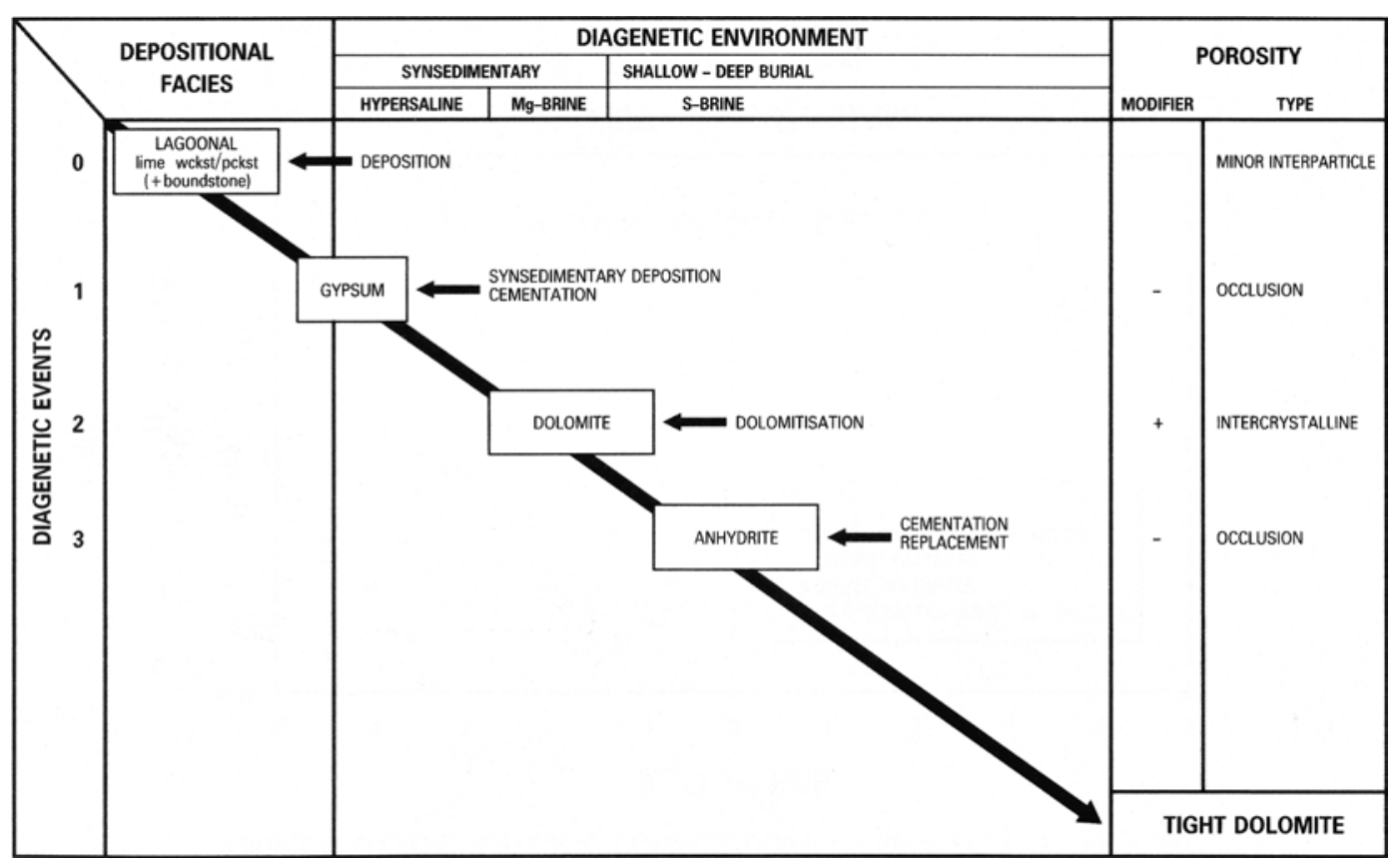

Fig. 18. Diagenetic model for lagoonal lime-wacke/packstones (reproduced, with permission from Springer Verlag, from Van de Sande et al., 2007).

ing fragments because the line of breakage is so fine, and tension gashes form along zones of ductile shear are very short/thin to short/ wedge-shaped. Tension gashes usually develop perpendicular to stylolites and are caused by the same stress field (Plate $8 \mathrm{C}$ ). They are the result of extension along the direction of minimum stress due to high fluid pressures (Nelson, 1985). Shear fractures are characterised by shear displacement along the fracture plane whereas hybrid fractures have a shear and an extensional component (Plate 8D). This combination may lead to brecciation of the fracture wall, perhaps by hydraulic bursting due to a sudden drop in fluid pressure in associated fracture zones.

Fractures may be visibly modified by diagenetic processes, as a result of which the space between the fracture walls can be widened further or be occluded (Plate $8 \mathrm{D}$ ). By petrographical and geochemical means, the various diagenetic events affecting fractures and the diagenetic evaluation can be reconstructed.

Fractures that are open (perhaps enhanced by leaching) are economically most significant and it is worthwhile attempting to reconstruct their geometry, notably their orientation (e.g., by palaeomagnetic orientation techniques).
Only limited attempts have been made in the carbonates under discussion here. From local palaeostress orientations established in cored intervals, stress-fracture relationships have been determined and the likely propagation direction of extension, shear and hybrid fractures are constrained. Extension fractures form parallel to the axis of the largest principal stress $\left(\sigma_{1}\right)$ and perpendicular to the axis of the least principal stress $\left(\sigma_{3}\right)$, upon relaxation of the compression. Shear fractures form at an angle of $30^{\circ}$ to $\sigma_{1}$ The intersection line of conjugate hybrid and/or shear fractures is parallel to the intermediate principal stress direction $\left(\sigma_{2}\right)($ Plate $8 \mathrm{~A})$.

Additional information about the palaeostress orientation is derived from stylolites. The stylolite plane, irregular due to the shape of the 'styles' (Greek: columns), is thought to result from pressure solution along bedding planes or junctions of 'intervals with contrasting depositional textures', normally perpendicular to the direction of $\sigma_{1}$ at the time of stylolitisation (Plate 8C). The fractures are observed to be largely area-dependent. The platform edge zone has been delineated as a potentially highly fractured area (Fig. 19). The fracture density in the ZEZ2C Carbonate Member increases from 


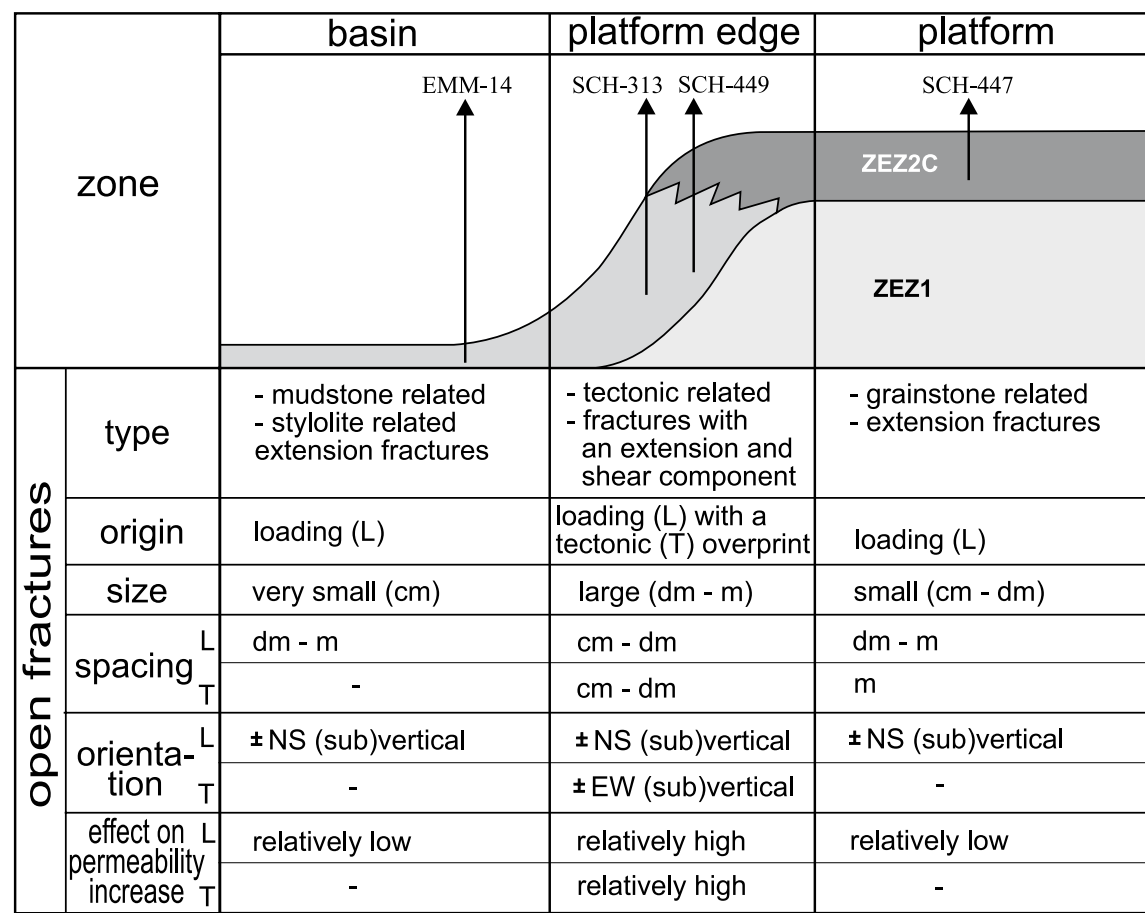

Fig. 19. Summary of the characteristics of open fractures, caused by loading (L) and tectonics (T) in the basin's distal-slope, platform-edge and platform-lagoon zones. Observations are mainly based on cores from wells from the Emmen and Schoonebeek fields (for location see Fig. 1) (reproduced, with permission from Springer Verlag, from Van de Sande et al., 2007). the basin, via the slope, towards the platform edge. The following factors may have played a role:

(1) the major sediment accumulation was in the slope facies; consequently loading fractures are here more common (Fig. 13);

(2) pre-Zechstein faulting determined the location of the ZEZ1A sulfate platform and consequently of the shelf edge; these faults were repetitively reactivated;

(3) the transition between the brittle platform area and the relatively ductile slope area determines a 'weak' zone in which (open) fractures could form.

The fractures are less densely developed on the platform interior than around the platform edge. Detailed studies on fractures in cores from individual gas fields showed that a genetic relationship exists between local (well) and sub-regional (field-scale) seismically undetectable fracture patterns on the one hand and fault patterns detectable on 3-D seismic on the other hand. The orientation of fault-related fractures is associated with the (strike-) slip component on the nearer fault. The fracture patterns are also influenced by nearby small faults. Thus, a local fault pattern that is detectable on 3-D seismic allows fracture predictions and ensuing reservoir permeability prediction in undrilled areas.

\section{Prediction of depositional- diagenetic porosity trends}

Figure 9 comprises representative photographs from Plates 1-7, depicting aspects of the seven facies zones discussed above. The alternation of core and microphotographs allows recognition of the salient features that were discussed above. The facies of the proximal slope, the open shelf and the barrier/shoal are supplemented by the diagenetic models that were discussed. This shows how these depositional facies were changed by a firm sequence of porosity-affecting diagenetic processes into leached dolomite, vuggy secondary limestone and vuggy dolomite CFUs with reservoir porosities from $10 \%$ to $20 \%$. By combining Figures 8 and 9 , a complete predictive depositional/diagenetic model is available. By attaching the summary of the characteristics of the open fractures and their distribution (Fig. 19), as well as the time isochore map of the Basal Zechstein Unit (Fig. 13) to this model, we have all the tools needed to predict reservoir trends. 
Fig. 20. Well logs and reflectivity synthethics of the Zechstein Group for a platform setting. The density and velocity values are low, and the base-ZEZ2C Carbonate Member reflection is stronger if the average porosity of the ZEZ2C is high. In this example, the porosity is, on average, 14\% (from Geluk, 2007, after Geluk, 1999, and Geluk \& Mijnlieff, 2001).

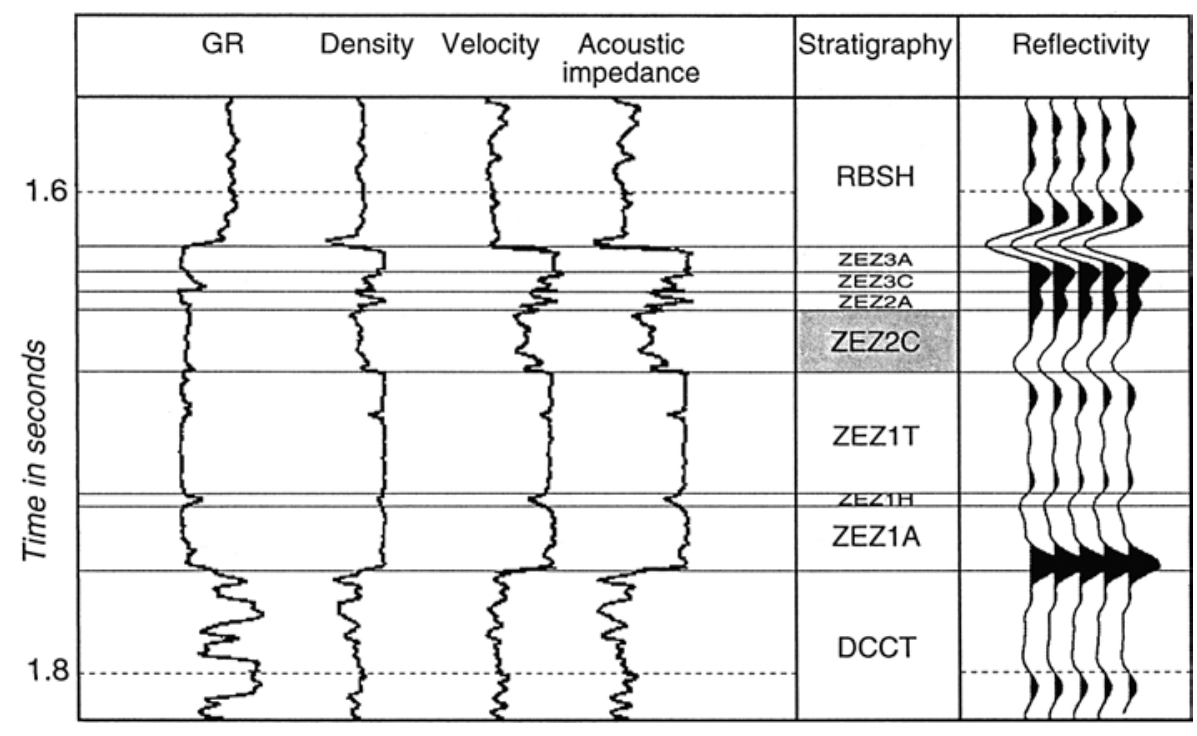

As it is not possible to resolve the ZEZ2C Carbonate Member on seismic because of its restricted thickness, one has to look at variations in porosity that are reflected in the seismic response, particularly in the platform areas where porosities are generally highest. Due to increased porosities, both the wire-line log density and the velocity drop an acousticimpedance contrast is generated that results in additional seismic reflections directly below the regional Top-ZEZ2A reflection (Fig. 20). Although such observations have already been made before on 2-D seismic, such efforts were limited by spatial restriction to the line of the seismic section on which the prediction was performed. With 3-D seismic, quantitative predictions and attribute measurements became possible on the regional ZEZ2A reflection and on additional reflections of the base of the ZEZ2C reservoir. The thickness variations and the local variations in acoustic impedance of the over- and underlying layers of ZEZ2C were studied (as reported by Van de Sande et al., 1996), and variations in the sedimentological characteristics over the study area were established (as reported here), in order to determine which seismic attributes (e.g. amplitude, loop area, and loop width) are best suited to predict specific reservoir parameters (porosity, thickness and pore volume). The targeting and delineation of reservoir zones in the Collendoornerveen field (CLDV in Fig. 13) (Van de Sande et al., 1996) demonstrates that in this way new exploration areas can be found in the now mature Zechstein hydrocarbon province.

\section{Conclusions}

Sedimentological core studies, detailed thinsection studies and supplementary representative stable-isotope values allowed recognition of basinal, slope, open-shelf, barrier/shoal and lagoon facies. Combined they give a depositional model for the ZEZ2C Carbonate Member of the Late Permian Zechstein 2 (Stassfurt) Formation in the subsurface of southeastern Drenthe (The Netherlands).

Diagenetic studies on representative samples of above facies allowed recognition of five Carbonate Fabric/Reservoir Units, respectively: Tight Secondary Limestone, Leached Dolomite, Vuggy Secondary Limestone, Vuggy Dolomite and Tight Dolomite. Attached to the depositional model they complete the sedimentation/diagenesis model of the ZEZ2C Carbonate Member. Three of these (the Leached Dolomite, the Vuggy Secondary Limestone and the Vuggy Dolomite) have economic reservoir quality.

The thickness of the ZEZ2C Carbonate Member is unresolvable on seismic, but variations in porosity and thickness, particularly in the platform areas, are reflected in the seismic response, and the wire-line log density. Modern 3-D seismic allows quantitative predictions 
and attributes measurements on reflection of the ZEZ2A Anhydrite Member and the base of the ZEZ2C Carbonate Member reservoirs. These, together with the sedimentological characteristics, allowed targeting and delineation of reservoir zones in the Collendoornerveen field, thus adding new exploration areas in an otherwise mature Zechstein hydrocarbon province.

\section{Acknowledgements}

I am indebted to the Nederlandse Aardolie Maatschappij for granting permission to publish the present study. Parts of the sedimentological work, providing a basis for the diagenetic study (which is presented here), were earlier published in 'Geology of gas and oil under The Netherlands', edited by H.E. Rondeel, D.A.J. Batjes \& W.H. Nieuwenhuys (1986). Many of the petrographical data were collected by my colleague D. van der Baan, whose responsibilities I took over upon his transfer from NAM. Together with colleagues in NAM, in particular G.P. van der Bilt, an internal report was produced which forms the basis for the present study. Dr M. van Steenwinkel, then a student of the Vrije Universiteit Amsterdam, supervised by Dr H.E. Rondeel, carried out the detailed fracture studies that are reported here. I thank the two reviewers whose suggestions considerably improved the manuscript. I also thank the copyright holders (NAM, Royal Netherlands Academy of Arts and Sciences, Kluwer Academic Publishers) for permission to reproduce here several illustrations from previously published works.

\section{References}

Adrichem Boogaert, H.A. \& Kouwe, W.F.P., 1993. Stratigraphic nomenclature of the Netherlands, revision and update by RGD and NOGEPA. Mededelingen Rijks Geologische Dienst 50.

Allen, J.R. \& Matthew, R.K., 1982. Isotope signatures associated with early meteoric diagenesis. Sedimentology 29, 797-817.

Badiozamani, K., 1973. The Dorag-dolomitisation model - application to the Middle Ordovician of Wisconsin. Journal of Sedimentary Petrology 43, 965-984.

Brongersma-Sanders M., 1971. Origin of major cyclicity of evaporates and bituminous rocks: an actualistic model. Marine Geology 11, 123-144.

Clark, D.N., 1986. The distribution of porosity in Zechstein carbonates. [In:] J. Brooks, Goff, J.C, \& Hoorn, B. van (Eds.). Habitat of Palaeozoic gas in N.W. Eu- rope. Geological Society, London, Special Publication 23, 167-203.

Esteban, M. \& Klappa, C.F., 1983. Subaereal exposure. [In:] Scholle, Bebout \& Moore (Eds): Carbonate depositional environments. American Association of Exploration Geologists Memoir 33, 1-54.

Geluk, M.C., 1999. Late Permian (Zechstein) rifting in The Netherlands: models and implications for petroleum geology. Petroleum Geoscience 5, 189-199.

Geluk, M.C., 2000. Late Permian (Zechstein) carbonate facies maps, The Netherlands. Netherlands Journal of Geosciences / Geologie en Mijnbouw 79, 17-27.

Geluk, M.C. 2005. Stratigraphy and tectonics of Permo-Triassic basins in The Netherlands and surrounding areas. Ph. D. thesis Utrecht University, 171 pp.

Geluk, M.C. 2007. Permian. [In:] Th.E. Wong, D.A.J. Batjes \& J. de Jager (Eds): Geology of The Netherlands. Royal Netherlands Academy of Arts and Sciences, Amsterdam, 63-83.

Geluk, M.C. \& Mijnlieff, H.F., 2001. Controls on the distribution and thickness of Permian basal Upper Rotliegend sandstones, The Netherlands: probing the limits of the Rotliegend play area. Extended abstract $63^{\text {rd }}$ Conference of the European Association of Geoscientists and Engineers (Amsterdam, 2001), P522.

Geluk, M.C., Plomp, A. \& Van Doorn, Th.H.M., 1996. Development of the Permo-Triassic succession in the basin fringe area, southern Netherlands. [In:] H.E. Rondeel, D.A.J. Batjes \& W.H. Nieuwenhuijs (Eds): Geology of gas and oil under The Netherlands. Kluwer, Dordrecht, 57-78.

Geluk, M.C., Van Wees, J.D., Grönloh, H. \& Van Adrichem Boogaert, H.A., 1997. Palaeogeography and palaeotectonics of the Zechstein (Upper Permian) in The Netherlands. Proceedings $13^{\text {th }}$ International Congress on Carboniferous-Permian (Kraków, 1995). Prace Panstwowego Geologicznego 157 (2), 63-75.

Geluk, M.C., Brückner-Röhling, S. \& Röhling, H.-G., 2000. Salt occurrences in the Netherlands and Germany: new insights in the formation of salt basins. [In:] R.M. Geertman (Ed.): Proceedings of the $8^{\text {th }}$ World Salt Symposium. Elsevier (Amsterdam), 131-136.

Glennie, K.W., Higham, J. \& Stemmerik, L., 2003. Permian. [In:] D. Evans, C. Graham, A. Armour \& P. Bathurst (Eds): The millenium atlas: petroleum geology of the central and northern North Sea. Geological Society, London, 91-103.

Hollingworth, N. \& Tucker, M.E., 1987. The Upper Permian (Zechstein) Turnstall Reef of North East England: palaeoecology and early diagenesis. Lecture Notes in Earth Sciences (Springer, Heidelberg) 10, 23-50.

Hollingworth, N. \& Pettygrew, T., 1988. Zechstein reeffossils and their paleoecology. Palaeontological Association /University Press, Oxford, 75 pp.

Johnson, H., Warrington, G. \& Stoker, S.J., 1994. Permian and Triasic of the southern North Sea. [In:] R.W.O'B Knox \& W.G. Cordey (Eds): Lithostratigraphic nomenclature of the North Sea. British Geological Survey, Nottingham.

Kerkman, K. 1969. Riffe und Algenbänke in Zechstein von Thüringen. Freiberger Forschunshefte, 85 pp. 
Logan, B.W., 1974. Inventory of diagenesis in HoloceneRecent carbonate sediments, Shark Bay, Western Australia. [In:] Logan et al. (Eds): Evolution and diagenesis of Quaternary carbonate sequences, Shark Bay, Western Australia. American Association of Petroleum Geologists Memoir 22,195-247.

Lohmann, K.C.,1988. Geochemical patterns of meteoric diagenetic systems and their application to studies of paleokartst. [In:] N.P. James \& P.W. Choquentte (Eds), Paleokarst. Springer Verlag, New York, 58-80.

Lokhorst, A. (Ed.), 1998. The Northwest European Gas Atlas. Netherlands Institute of Applied Geosciences TNO, Haarlem.

Moore, C.H. 1989. Carbonate diagenesis and porosity. Developments in Sedimentology (Elsevier, Amsterdam) 46, 398 pp.

Moore, C.H. 2001. Carbonate reservoirs - porosity evolution and diagenesis in a sequence stratigraphic framework. Developments in Sedimentology (Elsevier, Amsterdam) 55, 444 pp.

Nelson, R.A., 1985. Geologic analysis of naturally fractured reservoirs. Contributions to Petroleum Geology $\mathcal{E}$ Engineering (Gulf Publishing Company, Houston) 1, $320 \mathrm{pp}$.

Paul, J., 1980. Upper Permian algal stromatolitic reefs. Harz Mountains (F. R. Germany). Contributions to Sedimentology 9, 253-268.

Paul, J., 1991. Stromatolite reefs of the Upper Permian Zechstein Basin. Göttinger Arbeiten zur Geologie und Paläontologie 2, 325-328.

Paul, J., 2005. Permo-Carboniferous paleosols in central Germany. Hallesches Jahrbuch für Geowissenschaften B19, 25-35.

Peryt, T.M., 1986. The Zechstein (Upper Permian) Main Dolomite deposits of the Leba elevation, northern Poland: facies and depositional history. Facies 14, 151-200.

Peryt, T.M., 1978. Sedimentology and palaeoecology of the Zechstein Limestone (Upper Permian) in the ForeSudetic area (western Poland). Kwartalnik Geologiczny 22, 59-82.

Peryt, T.M., Geluk, M., Mathiesen, A., Paul, J. \& Smith, K., 2010. Zechstein. [In:] H. Doornbal \& A. Stevenson (Eds): Petroleum geological atlas of the Southern Permian Basin area. EAGE Publications, Houten, 123-147.

Reijers, T.J.A. \& Bartok, P., 1977. Depositional patterns and diagenetic sequences in Cretaceous Cogollo Group, Maracaibo Platform, Venezuela. American Association of Petroleum Geologists Bulletin 61, 821-822.

Reijers, T.J.A. \& Bartok, P., 1985. Porosity characterisation and evolution in fractured Cretaceous carbonate reservoirs, Venezuela. [In:] P. Roehl \& Ph.W. Choquette (Eds): Carbonate petroleum reservoirs. Springer, New York, 409-423.

Reijers, T.J.A. \& Van der Bilt, G.P., 1991. Diagenetic and fracture control on prospectivity in Zechstein-2 carbonates NE-Netherlands - Part II - annotated photo atlas. NAM internal report 17972-2, 18 pp. + plates.

Richter-Bernburg, G., 1986. Zechstein 1 and 2 anhydrites: facts and problems of sedimentation. [In:] G.M. Harwood \& D.B. Smith (Eds): The English Zechstein and related topics. Geological Society, London, Special Publication 22: 157-163.

Schlager, W., 2005. Carbonate sedimentology and sequence Stratigraphy. [In]: (L.J. Crossey (Ed.): Concepts in sedimentology and paleontology. Society of Economic Petrologists and Mineralogists Special Publication 8, $200 \mathrm{pp}$.

Smith, D.B., 1981a. The Magnesian Limestone (upper Permian) reef complex in northeastern England. Society of Economic Paleontologists and Mineralogists Special Publication 30, 161-186.

Smith, D.B., 1981b. Bryozoan-algal patch-reefs in the Upper Permian Lower Magnesian Limestones of Yorkshire, northeastern England. Society of Economic Paleantologists and Mineralogists Special Publication 30, 187-202.

Smith, D.B., 1989. The late Permian palaeogeography of northeastern England. Proceedings of the Yorkshire Geological Society 97, 285-312.

Smith, D.B., 1995. Marine Permian of England. Chapman \& Hill, London, 205 pp.

Strohmenger, C., Rockenbauch, K. \& Waldmann, R., 1998. Fazies, Diagenesis und Reservoirentwicklung des Zechstein-2 Karbonate (Ober Perm) in Nordostdeutschland. Geologisches Jahrbuch A 149, 81-113.

Taylor, J.C.M., 1998. Upper Permian-Zechstein. [In:] K.W. Glennie (Ed.): Petroleum Geology of the North Sea (4 $4^{\text {th }}$ ed.). Blackwell Sciences, Oxford, 174-212.

Tucker, M.E. \& Wright, V.P., 1990. Carbonate sedimentology. Blackwell Scientific Publishers, Oxford, 481 pp.

Van Adrichem Boogaert, H.A. \& Kouwe, W.F.P., 1994. Stratigraphic nomenclature of The Netherlands: revision and update by RGD and NOGEMPA - Section D, Permian. Mededelingen Rijks Geologische Dienst 50.

Van der Baan, D., 1987. Secondary limestones and leached dolomites of the Zechstein-2 Carbonate, well Woudsend-1. XEX/7 Sedimentological Note 30 (unpublished NAM report).

Van der Baan, D., 1990. Zechstein reservoirs in The Netherlands. [In:] J. Brooks (Ed.): Classic petroleum provinces. Geological Society, London, Special Publications 50, 379-398.

Van de Sande, J.M.M., Reijers, T.J.A. \& Casson, N., 1996. Multidisciplinary exploration strategy in the northeast Netherlands Zechstein 2 Carbonate play, guided by 3D seismic. [In:] Rondeel, H.E., Batjes, D.A.J. \& Nieuwenhuijs, W.H. (Eds): Geology of gas and oil under The Netherlands. Kluwers Academic Publishers, Dordrecht, 125-142.

Wagner, R., 1994. Stratigraphy and evolution of the Zechstein basin in the Polish Lowlands. Prace Panstwowego Instytutu Geologiczneo 146, 71 (English translation by the Polish Geological Institute), 146- 171.

Ziegler, P.A., 1990. Geological atlas of western and central Europe ( $2^{\text {nd }} e d$.). Geological Society Publishing House, Bath, 239 pp.

Manuscript received: 5 July 2012 Revision accepted: 1 September 2012 

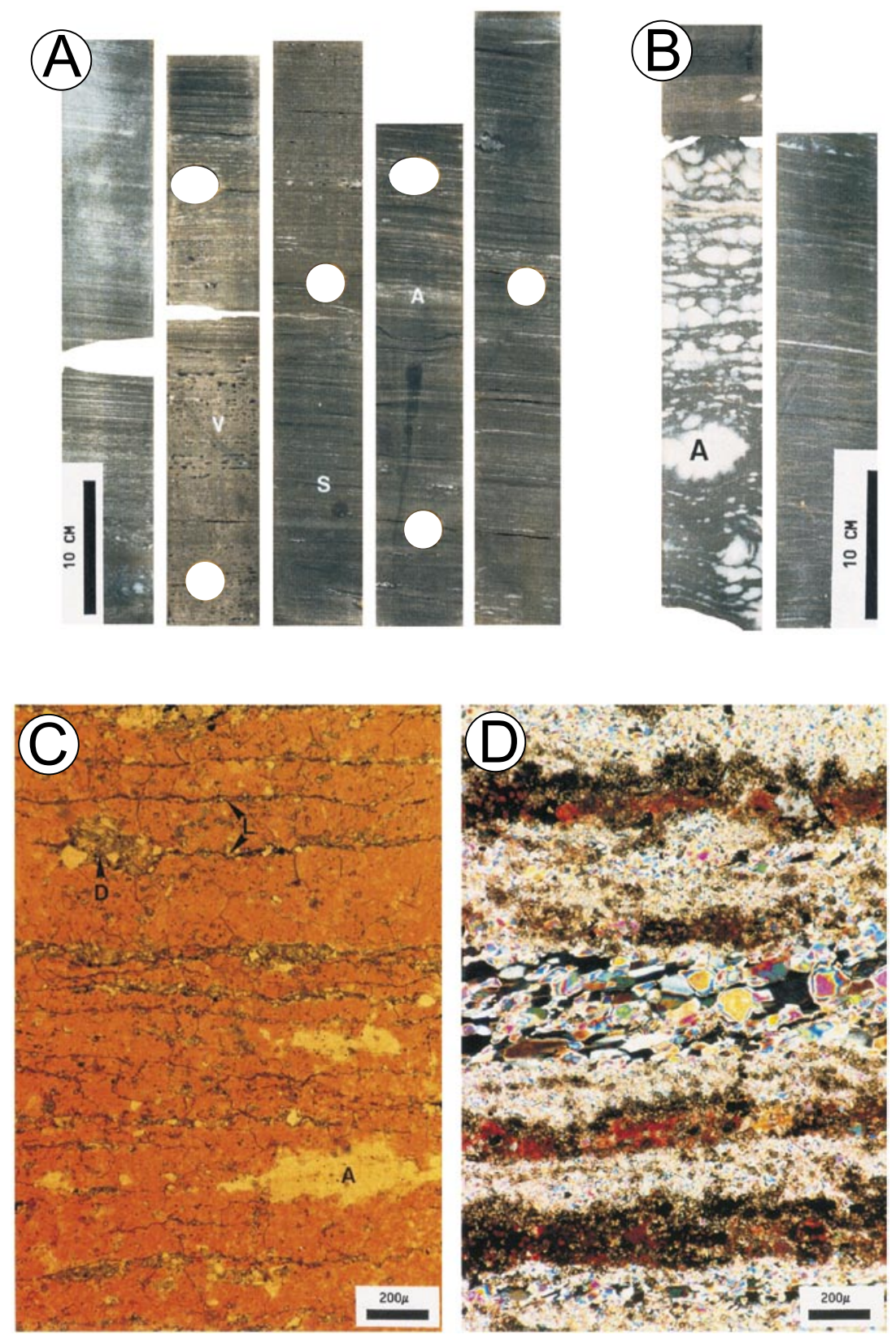

Plate 1. Basin facies and tight secondary limestone CFU.

A: Characteristic appearance of basin carbonates. The carbonate is a millimetre-laminated dolomitised lime-mudstone. Note the common white anhydrite laminae (A), disconnected vugs (V), and occasional irregular dark-brown to black seams (S). The top $40 \mathrm{~cm}$ of the succession (at left) consists of laminated anhydrite (ZEZ2A). Well 9, 3451.00$3453.55 \mathrm{~m}$.

B: Millimetre-laminated, organic-rich basin carbonates devoid of bioclasts and fossils. The carbonates initially consisted of dolomitised lime-mudstone, but are now completely calcitised (dedolomitised). Anhydrite laminae occur commonly, grading into anhydrite nodular beds (A). Well 9, 3460-3461.00 m.

C: The tight dedolomite. An almost completely dedolomitised (calcitised) mineralogy is demonstrated by the red staining with Alizarin-Red-S. Remnants of laminae (L) formed by depositional processes and dolomite patches (D) suggest that the original fine-grained lime-mudstone was dolomitised and subsequently calcitised. Note the anhydrite patches (A), with dolomite relicts and corroded margins, indicating that the anhydrite formation postdates the dolomitisation but predates the calcite precipitation. Well 4, 3201.1 m. Plane polarised light.

D: Varve-like laminae with organic matter. Originally a laminated lime-mudstone, but replaced by dolomicrite and subsequently partially replaced by calcite (red stained with Alizarin Red-S) and very fine to medium crystalline anhydrite. Dolomite relicts indicate that calcite and anhydrite postdate the dolomite precipitation. Well 1, depth unknown. Crossed nicols. 


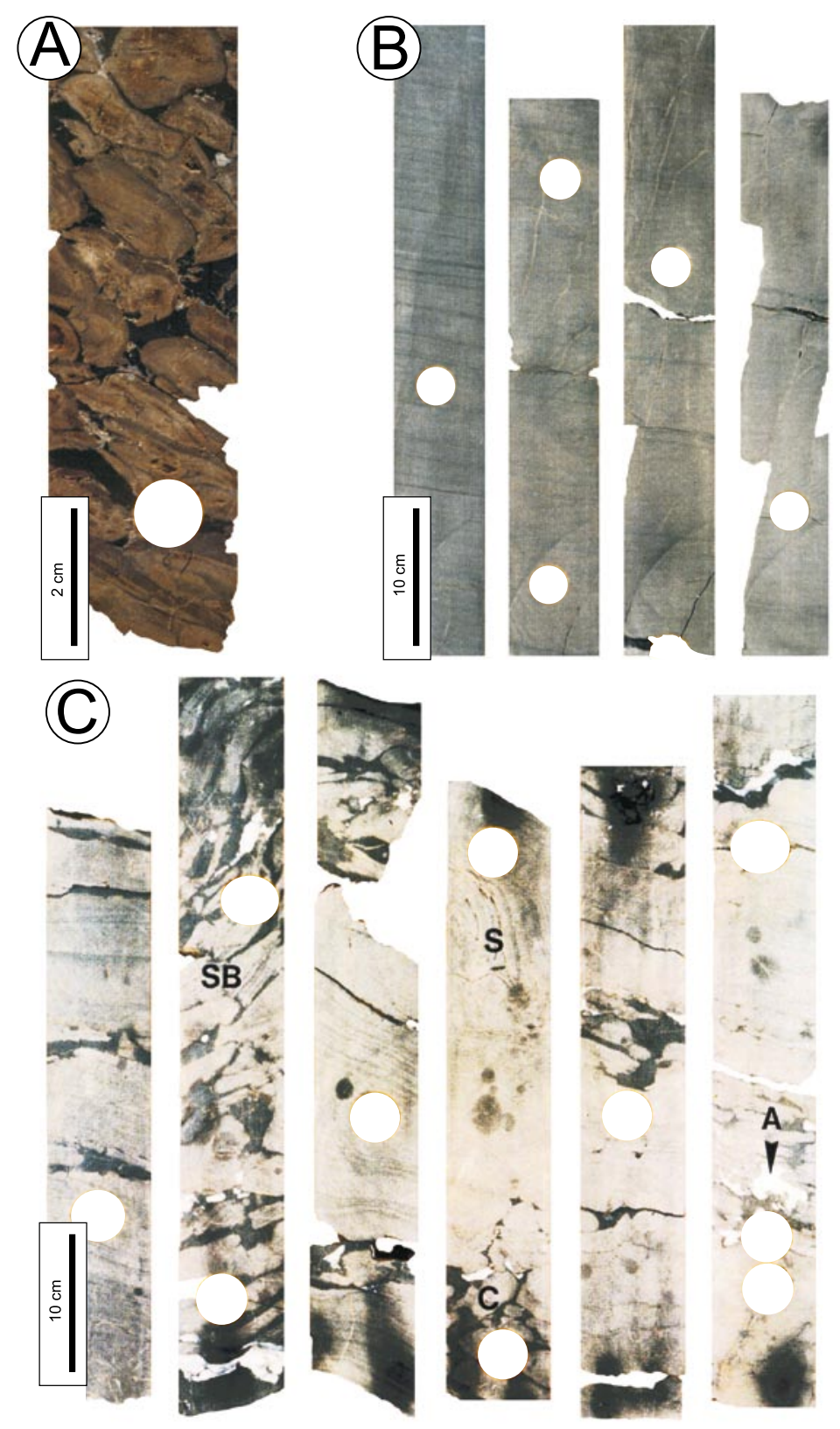

Plate 2. Slope facies and leached dolomite CFU.

A: Conglomeratic debris-flow material with appreciable intergranular porosity, light brown clasts of dolomitised lime-mudstone in a matrix of dark brown dolomite. The clasts are fragments of semi-lithified, redeposited slope sediments, possibly including early-diagenetic carbonate concretions. Well 11, depth 3246.85-3247.15 m.

B: Centimetre-bedded dolomitised lime-mudstone with, in the top part, millimetre-sized laminae, reflecting stacked mudstone turbidites, deposited in the distal part of the slope. Well 7, depth 3958.60-3960.53 m.

C: Secondary limestone with patches of dark grey, leached dolomite occurs in a succession of stacked turbidites, and includes a slumped interval (S), a slope breccia (SB) and concretions (C), collectively characterising a slope facies. The leached but mineralogical unaltered dolomite occasionally contains patches of white, partly calcitised, anhydrite (A), suggesting that the host dolomite formed a pathway for diagenetic fluids, resulting in the secondary limestone and the calcitised anhydrite. Well 10, depth3120.90-3123.70 m. 

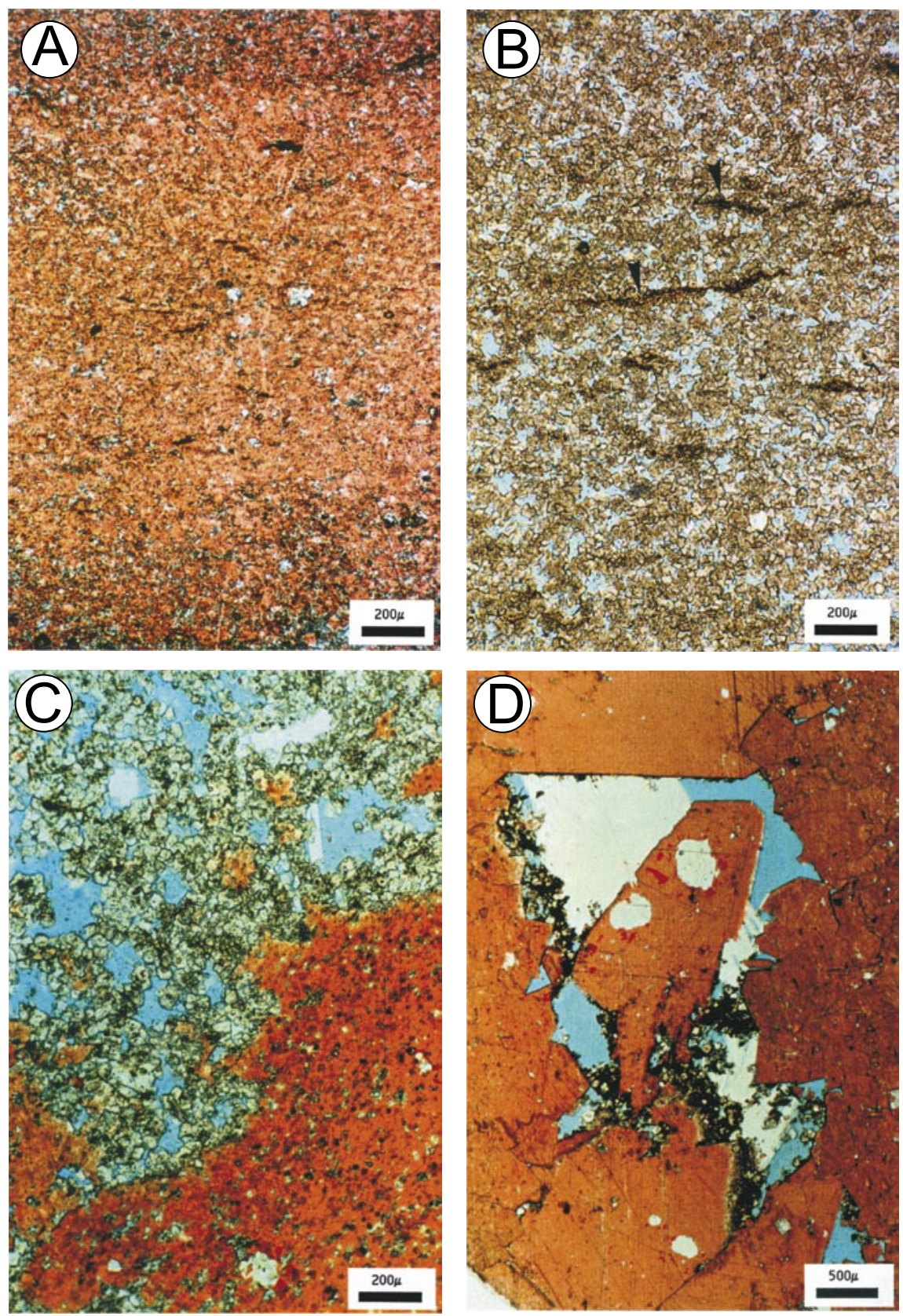

Plate 3. Slope facies and leached dolomite CFU.

A: Tight secondary limestone, the result of complete calcitisation by incongruent dissolution as a result of moderate partial pressure of $\mathrm{CO}_{2}$. Note the faint relict of lamination. Well 19, depth $1949.6 \mathrm{~m}$. Plane polarised light.

B: Porous vuggy dolomite, the result of congruent dissolution (dolomite leaching) triggered by the generation of large amounts of $\mathrm{CO}_{2}$. Note the relict of lamination (arrowed). Well 19, depth $1949.0 \mathrm{~m}$. Plane polarised light. The generation of $\mathrm{CO}_{2}$ from organic matter during burial potentially produces a spectrum of CFU (see also Fig. 14). The two end members of this spectrum are shown on Plate 3A, B, respectively. With steady increase of the partial $\mathrm{CO}_{2}$ pressure, generated from organic matter during burial, calcitisation by incongruent dissolution diminishes in importance and dolomite leaching by congruent dissolution increases. Plate $3 \mathrm{C}$ and D shows the effects of increased dolomite leaching on the rock fabric.

C: Detail of an advanced stage of calcitisation and subsequent significant dolomite leaching. Note the relict patches of leached dolomite within the tight secondary limestone. Note also the late pore-filling anhydrite cement (white) in the upper half of the photo. Well 19, depth $1953.5 \mathrm{~m}$. Plane polarised light.

D: Final stage of dolomite leaching subsequent to calcitisation. The vug within the secondary limestone represents former dolomite, now a vug due to leaching. Relicts of dolomite can be seen in the vug. Note the large calcite crystals lining the vug and late anhydrite cements. Well 19, depth $1960.4 \mathrm{~m}$. Plane polarised light. 

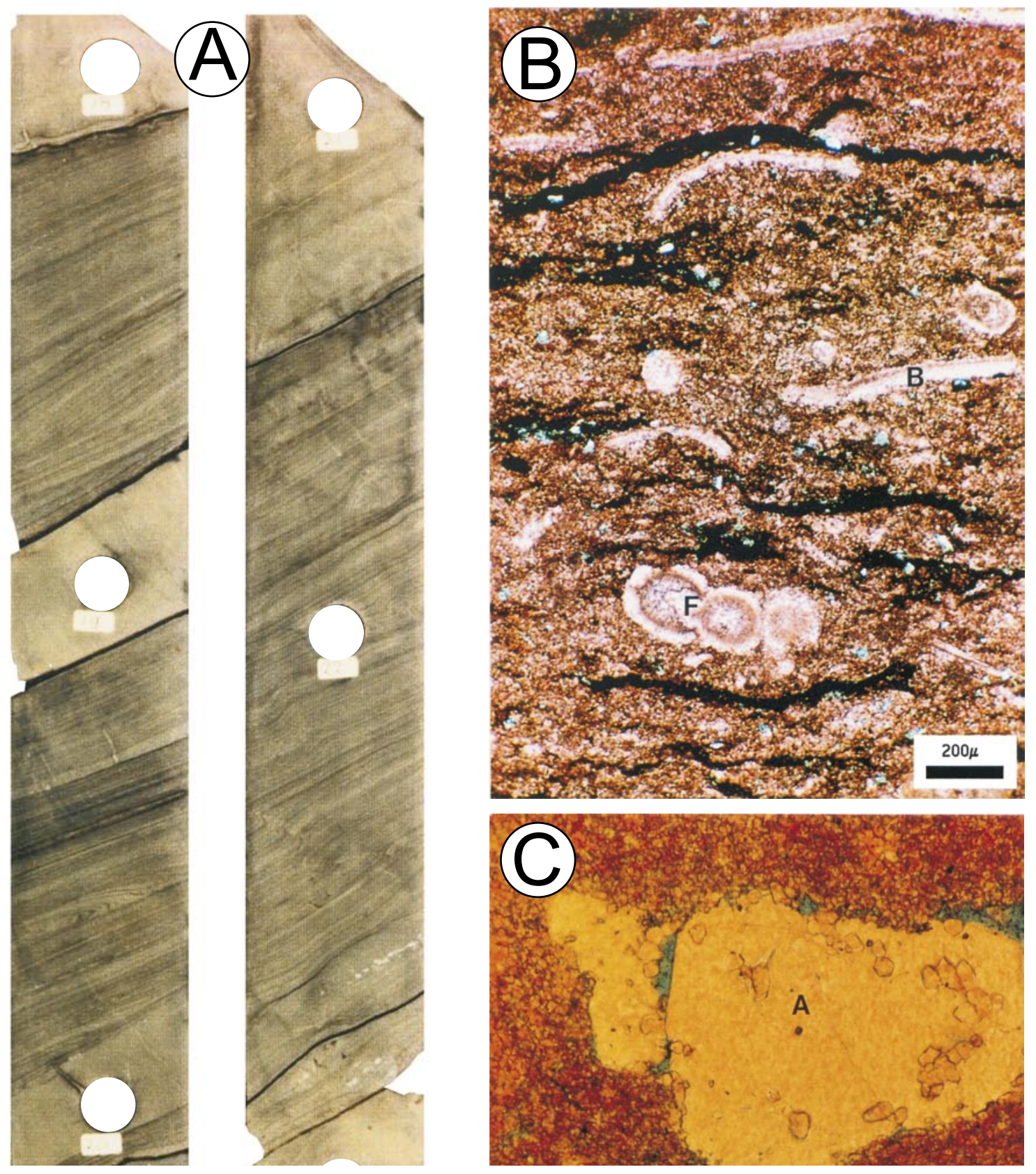

Plate 4. Open-shelf facies and vuggy secondary limestone CFU.

A: Open-shelf wackestones, showing an alternation of centimetre-scale bedded intervals reflecting low-energy conditions, and decimetre-scale bedded carbonates, possibly reflecting storm conditions. Note that the colour is somewhat lighter than that of the basin facies (Plate 1). Well 2, depth 3719/46-3723.0 m.

B: Well bedded, comparably tight secondary wackestone (unstained thin section) from the shallow-marine facies showing abundant bioclastic bivalves (B) and nodosarid foram (F). Well 15, depth $3725.10 \mathrm{~m}$. Plane polarised light. C: Leached dedolomite showing vugs (V) which are partly plugged with anhydrite-cement (A). Note the (diagnostic) presence of bioclasts (B). Well 2,depth $3723.1 \mathrm{~m}$. Plane polarised light. 


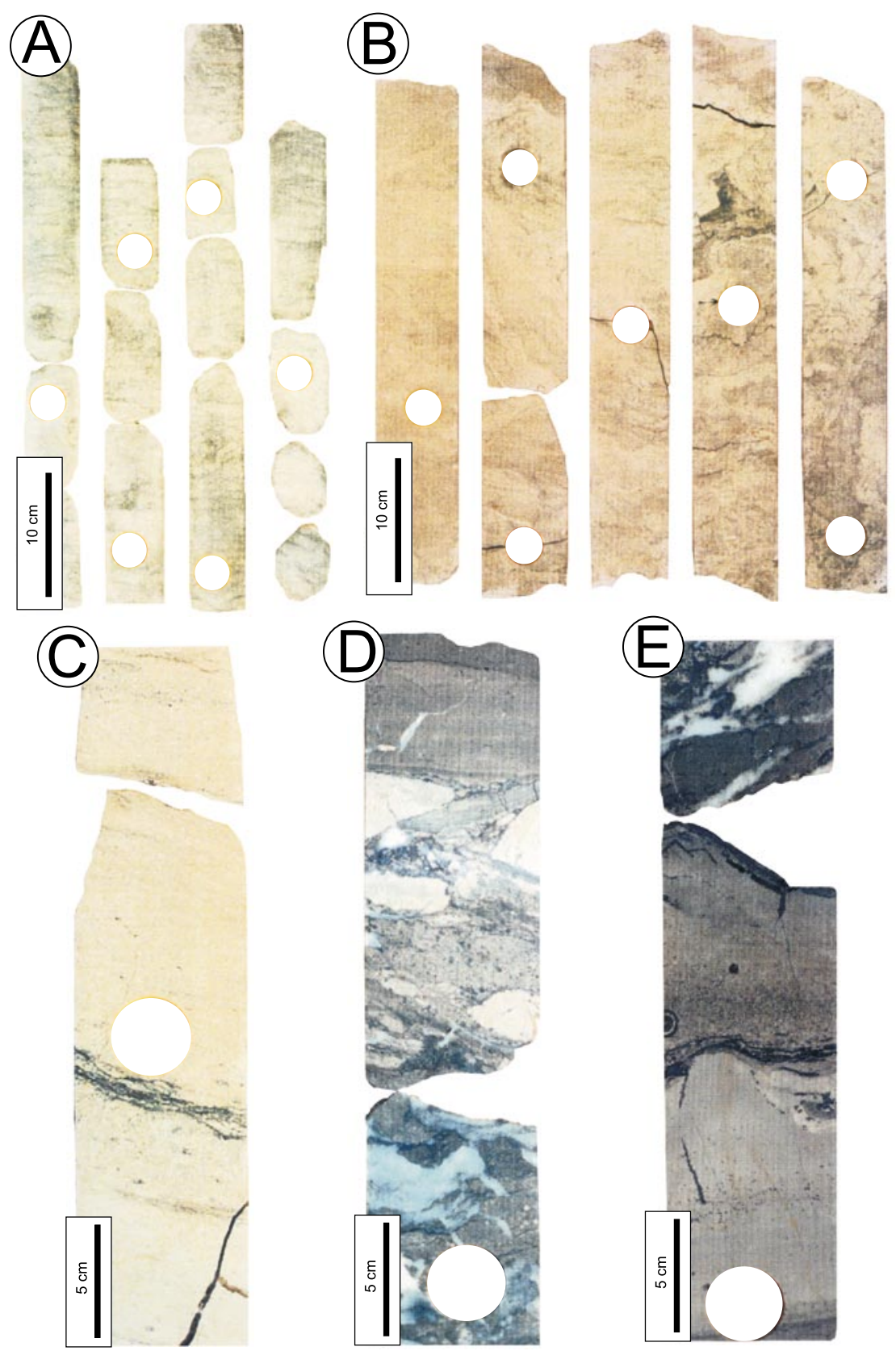

Plate 5. Barrier/shoal facies and vuggy dolomite CFU.

A: A light-coloured dolomitised grainstone composed of millimetre- to centimetre-sized coated clasts and ooids (see Plate 6). The beds are internally massive, and the bedding is not always clear. Where it is discernible, it is centimetrescale parallel wavy bedding. The abundantly occurring coated lumps display a micro-pelletoidal fabric and look similar to fragments of pavement breccias on present-day supratidal flats in Shark Bay, Western Australia. Well 16, depth 4235.60-4237.50 m.

B: Barrier/shoal dolomites with intercalated pavement breccia clasts (see Plate 5D) derived from a supratidal flat (see Plate 5E). The mottled appearance probably reflects widespread differential leaching, related to calcretisation taking place at the top of the emergent barrier/shoal. Note the triangular shape of the sediment-filled karst cavity at $2083.15 \mathrm{~m}$. Well 12, depth 2581.60-2583.95 m.

C: Poorly, centimetre-scale, wavy bedded ooid grainstone representing ooid shoals at the carbonate platform. Well 17, depth $1786.5 \mathrm{~m}$ (top).

D: Carbonate breccia derived from a supratidal pavement. The imbrication of clasts may reflect storm reworking. Well 17, depth $1828 \mathrm{~m}$ (top).

E: Laminar crust, probably formed as a calcrete hardpan. Ghosts of spherical structures in the overlying interval possibly represent diagenetically affected caliche glaebules. Well 17, depth $1829.5 \mathrm{~m}$ (top). 


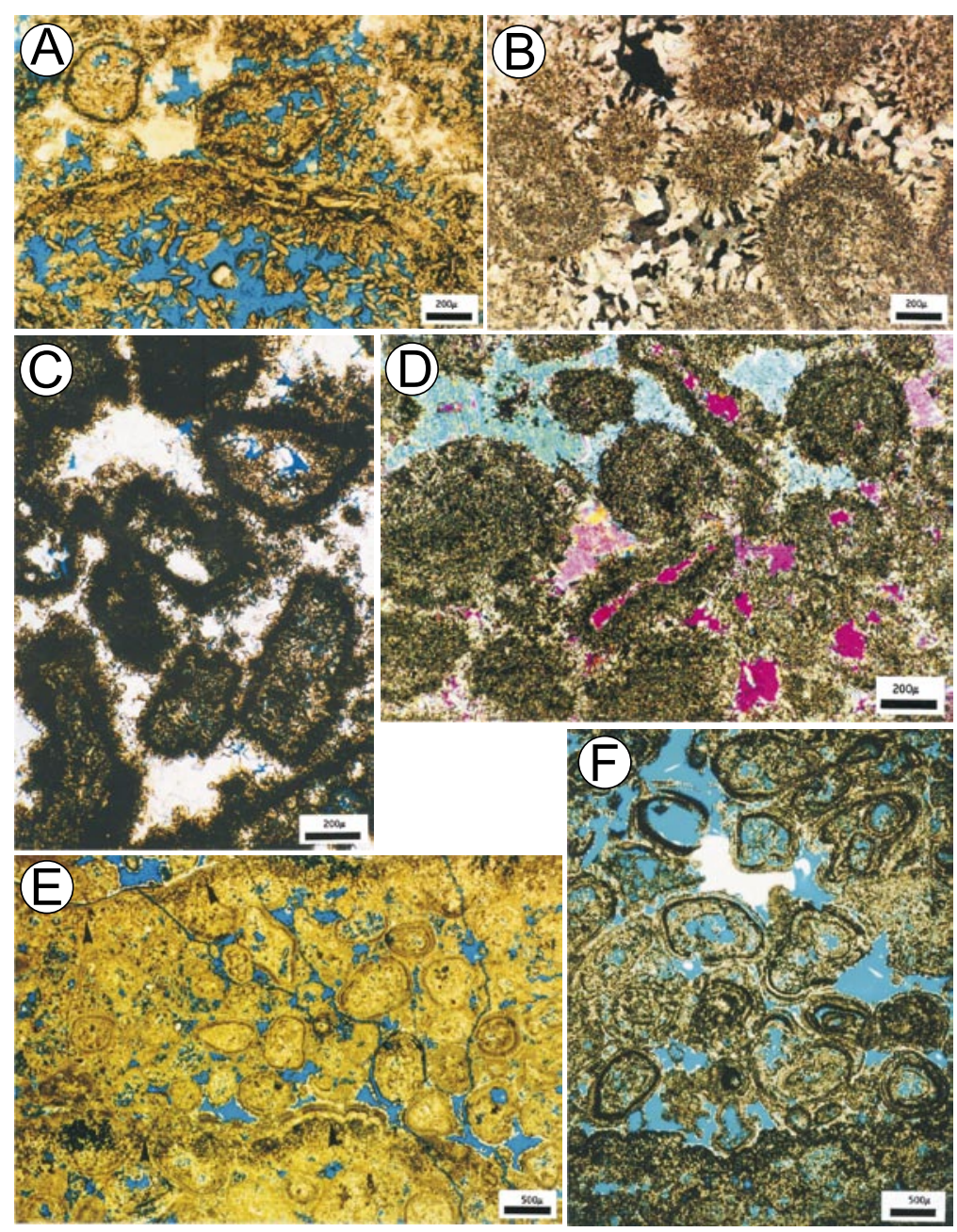

Plate 6. Barrier/shoal facies and vuggy dolomite CFU.

A: The main porosity-creating process in barrier/shoal sediments is leaching by meteoric water. This grainstone shows coated grains with a high intragranular porosity due to intense leaching. Intergranular pores are partly occluded by the late anhydrite cement. The micrite rim and isopachous rim cement suggest that the grainstone was initially cemented in a marine phreatic environment. The typical lath-shaped dolomite crystals appear to be characteristic of the vuggy dolomite CFU from the barriers/slope facies. Well 8, depth $3522.5 \mathrm{~m}$. Plane polarised light.

B: Coated-grain/peloid grainstone showing complete occlusion of the intergranular porosity by a dolomite cement. A first-generation (former aragonite?) isopachous acicular rim cement suggests early cementation in a phreatic marine environment. Well 6, depth $4276.5 \mathrm{~m}$. Plane polarised light.

C: Peloid/intraclast grainstone showing occlusion by anhydrite of the depositional intergranular porosity and intragranular porosity caused by leaching. The irregular rim cement (meniscus fabric?) suggests cementation in a vadose environment. The micritised grains possibly are fragments of algal mats reworked into low-energy intershoal areas. Well 18, depth $4010.40 \mathrm{~m}$. Plane polarised light.

D: Ooid grainstone of which inter- and intragranular porosity is completely occluded by anhydrite cement. The corroded margins of the ooids and the minor intragranular porosity suggest that anhydrite cementation was preceded by leaching. The high minus-cement porosity that characterises sedimentary material if it contained no chemical cement, indicates that dolomitisation, leaching and anhydrite plugging must have occurred before significant compaction. Note that the ooids are completely micritised. Well 17, depth $1787.3 \mathrm{~m}$. Crossed nicols with gypsum plate. E: Ooid/pisoid grainstone showing a complex (early) diagenetic history. Two micritised surfaces are visible, partly obliterating the original particles. Micritisation was followed by partial laminar coating and irregular rim cement (arrowed). Other characteristic features are fracturing, patchy micritisation, circum-granular cracking and cryptocrystalline meniscus-cement formation, followed by even rim cement formation and, locally, crystal silt accumulation. All these features point to a vadose environment with possibly soil/calcrete diagenesis. Well 3, depth 2428.774 m. Plane polarised light.

F: As above, but showing incipient vadose compaction, polygonal fitting and crystal silt accumulation, all characteristics of meteoric vadose diagenesis. Well 3, depth $2430.92 \mathrm{~m}$. Plane polarised light. 

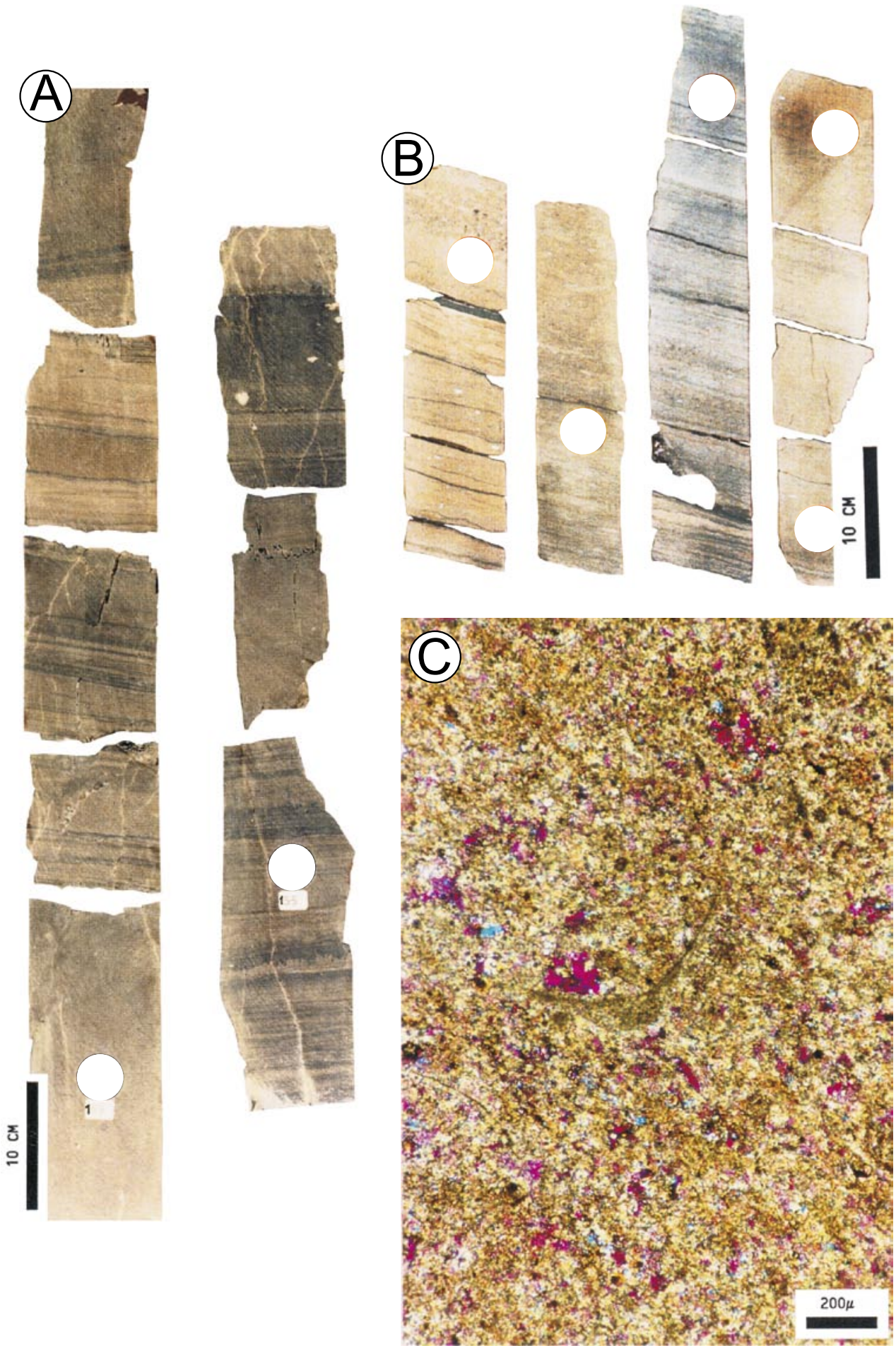

Plate 7. Lagoon facies and tight dolomite CFU.

A: Deep-lagoon carbonates. Well-developed, wavy millimetre-laminated to decimetre-scale bedding in a (dark) grey, dolomitised lime-mudstone. Note the frequent presence of horsetail splays developed at small-scale faults and stylolites and occasional small anhydrite nodules. Well 5, depth 1402.40-1404.0 m.

B: Shallow-lagoon carbonates. Well-bedded dolomitised lagoonal wacke/packstones, containing peloids, shell fragments and gastropods. Well 17, depth 1793.4-1798.0 m.

C: Shallow-lagoon tight dolomite. Dolomitisation largely obliterated the original peloid packstone texture. However, the distribution of the anhydrite cement allows occasionally recognition of ghosts of the original texture. Note the presence of dolomitised thin-walled bivalves. Dolomitisation and anhydrite cementation resulted in a tight dolomite. Well 17, depth $1793.8 \mathrm{~m}$. Plane polarised light with gypsum plate. 

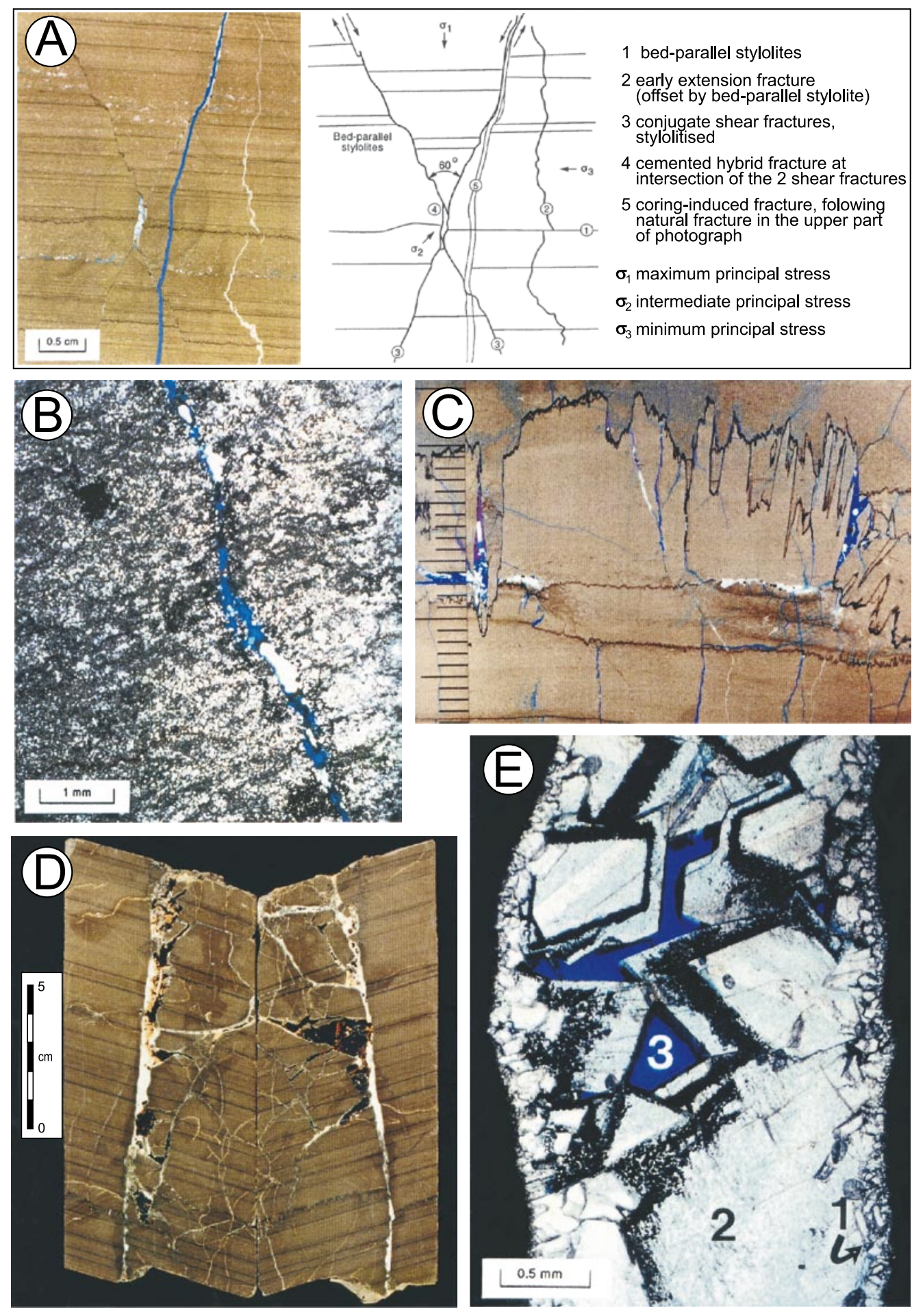

Plate 8. Fractures.

A: Coring-induced (blue) and natural fractures (extension, shear and hybrid) and related palaeostress. Well 7, depth $3977.10 \mathrm{~m}$.

B: Open 'hairline' fracture in carbonate mud, with black stain. Note the white cement patches infilling the fracture, indicating that the fracture is a natural one. Well 14, depth $3115 \mathrm{~m}$.

C: Stylolite-related extension fractures (scale bar in millimetres). Well 13, depth $2854 \mathrm{~m}$.

D: Hybrid fracture, mineralised with sphalerite and pyrite (scale bar $=5 \mathrm{~cm}$ ). Well 13, depth $3195.70 \mathrm{~m}$.

E: Fracture diagenesis: (1) early dolomite rim, (2) dolomite rhombs, rimmed with black stain, (3) open pores in some cases (partly) filled with anhydrite. Well 14, depth $3127.75 \mathrm{~m}$. 